\title{
$1 \quad$ Life histories and niche dynamics in late Quaternary proboscideans 2 from Midwestern North America: evidence from stable isotope 3 analyses
}

4 Chris Widga ${ }^{1,2}$, Greg Hodgins ${ }^{3}$, Kayla Kolis ${ }^{4}$, Stacey Lengyel ${ }^{1,2}$, Jeff Saunders ${ }^{2,5}$, J. Douglas

5 Walker $^{6}$, Alan D. Wanamaker ${ }^{7}$

7 Affiliations

8 1. Don Sundquist Center of Excellence in Paleontology, East Tennessee State University,

9 Johnson City, TN

10 2. Illinois State Museum, Springfield, IL

11 3. Department of Physics, University of Arizona, Tucson, AZ

12 4. Biodiversity Institute, University of Kansas, Lawrence, KS

13 5. The Desert Laboratory on Tumamoc Hill, University of Arizona, Tucson, AZ

14 6. Department of Geology, University of Kansas, Lawrence, KS

15 7. Department of Geological and Atmospheric Sciences, Iowa State University, Ames, IA

16

17 Key Words: Mammoths, Mastodons, Stable Isotopes, Paleoecology, Midwest, Mobility 


\section{ABSTRACT}

21 Stable isotopes of mammoths and mastodons have the potential to illuminate ecological changes

22 in late Pleistocene landscapes and megafaunal populations as these species approached

23 extinction. The ecological factors at play in this extinction remain unresolved, but isotopes of

24 bone collagen $\left(\delta^{13} \mathrm{C}, \delta^{15} \mathrm{~N}\right)$ and tooth enamel $\left(\delta^{13} \mathrm{C}, \delta^{18} \mathrm{O},{ }^{87} \mathrm{Sr} /{ }^{86} \mathrm{Sr}\right)$ from the Midwest, USA are

25 leveraged to examine ecological and behavioral changes that occurred during the last

26 interglacial-glacial cycle. Both species had significant $\mathrm{C} 3$ contributions to their diets and

27 experienced increasing levels of niche overlap as they approached extinction. A subset of

28 mastodons after the last glacial maximum (LGM) exhibit low $\delta^{15} \mathrm{~N}$ values that may represent

29 expansion into a novel ecological niche, perhaps densely occupied by other herbivores. Stable

30 isotopes from serial and micro-sampled enamel show increasing seasonality and decreasing

31 temperatures as mammoths transitioned from Marine Isotope Stage (MIS) 5e to glacial

32 conditions (MIS 4, MIS 3, MIS 2). Isotopic variability in enamel suggests mobility patterns and

33 life histories have potentially large impacts on the interpretation of their stable isotope ecology.

34 This study further refines the ecology of midwestern mammoths and mastodons demonstrating

35 increasing seasonality and niche overlap as they responded to landscape changes in the final

36 millennia before extinction. 


\section{INTRODUCTION}

Historically, the late Quaternary record of mammoths and mastodons in the Midwest has played an important role in understanding megafaunal extinctions in North America (e.g., Fisher 2008, 2018; Graham et al., 1981; Saunders et al. 2010; Widga et al., 2017a; Yansa and Adams, 2012). Whether extinctions are viewed as human-induced (Mosimann and Martin 1975; Alroy 2001; Surovell et al. 2005; Fisher 2009; Surovell et al. 2016), the result of late Pleistocene landscape changes (Stuart et al. 2004; Nogués-Bravo et al. 2008; Widga et al. 2017a), a function

44 of other ecological processes (Ripple and Van Valkenburgh 2010), or some combination, this region is unparalleled in its density of large, late Quaternary vertebrates and associated paleoecological localities. For these reasons, the midcontinent has proven critical to understanding ecological dynamics in proboscidean taxa leading up to extinction. In recent years, it has been recognized that multiple proboscidean taxa shared an ecological niche in late Pleistocene landscapes (Saunders et al. 2010) despite distinct extinction trajectories (Widga et al. 2017a). Chronological studies indicate that proboscideans in this region experienced extinction in situ, rather than mobilizing to follow preferred niche space (Saunders et al. 2010). Despite refinements in our understanding of mammoths and mastodons in the region, many significant questions remain. Modern megafauna have a profound impact on local vegetation (Guldemond and Van Aarde 2008; Valeix et al. 2011), and it is unclear what effect late Pleistocene mammoths and mastodons would have had on canopy cover, nutrient cycling, and fruit dispersal

56 in non-analogue vegetation communities. There are still issues of equifinality in how the

57 presence of human predators (Fisher 2009) or the virtual absence of both humans and large

58 carnivores (Widga et al. 2017a) impacted proboscidean populations in the region as they neared extinction. 
The high profile debate surrounding the cause of late Pleistocene megafaunal extinctions

61 has spurred a number of productive regional studies to address the timing and paleoecology of

62 extinction in megafaunal taxa (Pacher and Stuart 2009; Stuart and Lister 2011, 2012; Stuart

63 2015; Widga et al. 2017a). The results of this research serve to constrain the number of possible

64 extinction scenarios and to highlight the need for regional-scale and taxon-specific analyses.

As in modern ecosystems, Proboscidea in late Pleistocene North America were long-lived taxa that likely had a profound impact on the landscape around them. Due to their size and

67 energetic requirements, elephantoids are a disruptive ecological force, promoting open canopies

68 in forests through tree destruction (Chafota and Owen-Smith 2009) and trampling vegetation

69 (Plumptre 1994). Their dung is a key component of soil nutrient cycling (Owen-Smith 1992;

70 Augustine et al. 2003), and was likely even more important in N limited tundra and boreal forest

71 systems of temperate areas during the late Pleistocene. Even in death, mammoths and mastodons

72 probably wrought major changes on the systems within which they were interred (Coe 1978;

73 Keenan et al. 2018) providing valuable nutrient resources to scavengers and microbial

74 communities. Precisely because proboscideans play such varied and important roles in the

75 ecosystems they inhabit, they are good study taxa to better understand Pleistocene ecosystems.

76 They are also central players in many extinction scenarios.

77 One of the major challenges to ecological questions such as these is scale (Delcourt and

78 Delcourt 1991; Denny et al. 2004; Davis and Pineda-Munoz 2016). Processes that are acting at

79 the level of an individual or a locality can vary significantly in space and time (Table 1).

80 Paleoecological data collected from individual animals from local sites is constrained by larger

81 regional patterns that may or may not be apparent (e.g., taphonomic contexts, predator-prey

82 dynamics). Paleoecological studies of vertebrate taxa often begin with the premise that the 

both a benefit and a challenge to studies of proboscidean paleoecology.

86 Table 1. Scales of paleoecological analysis.

\begin{tabular}{|l|l|l|l|}
\hline Scale & Method & Phenomena & Selected References \\
\hline $\begin{array}{l}\text { Small } \\
\text { Days })\end{array}$ & $\begin{array}{l}\text { Stomach } \\
\text { contents, } \\
\text { enamel micro- } \\
\text { wear }\end{array}$ & $\begin{array}{l}\text { Animal health, Landscape (local } \\
\text { scale) }\end{array}$ & $\begin{array}{l}\text { Rhodes et al. 1998; Teale and Miller } \\
\text { 2012; Green, DeSantis, and Smith 2017; } \\
\text { Smith and DeSantis 2018. }\end{array}$ \\
\hline $\begin{array}{l}\text { Meso } \\
\text { (Weeks- } \\
\text { Months) }\end{array}$ & $\begin{array}{l}\text { Hair, } \\
\text { Tusk/Tooth } \\
\text { dentin, Tooth } \\
\text { enamel }\end{array}$ & $\begin{array}{l}\text { Seasonal diets, Reproductive } \\
\text { events (e.g., musth, calving), } \\
\text { Migration/Dispersal }\end{array}$ & $\begin{array}{l}\text { Fox and Fisher 2001; Hoppe 2004; } \\
\text { Hoppe and Koch 2007; Cerling et al. } \\
\text { 2009; Metcalfe and Longstaffe 2012; } \\
\text { Fisher 2018 }\end{array}$ \\
\hline $\begin{array}{l}\text { Large } \\
\text { (Years - } \\
\text { Decades) }\end{array}$ & $\begin{array}{l}\text { Bone } \\
\text { collagen, tooth } \\
\text { enamel, tooth } \\
\text { mesowear }\end{array}$ & $\begin{array}{l}\text { Climate/Vegetation trends, } \\
\text { Large-scale land-use trends, } \\
\text { Population-level trends in diet } \\
\text { responses to landscape changes. }\end{array}$ & $\begin{array}{l}\text { Bocherens et al. 1996; Iacumin et al. } \\
\text { 2010; Szpak et al. 2010 }\end{array}$ \\
\hline
\end{tabular}

87 Smith and DeSantis 2018) are increasingly sophisticated, and have the potential to track shortterm dietary trends. The remains of stomach contents also provide ecological information at this scale (Lepper et al. 1991; Newsom and Mihlbachler 2006; van Geel et al. 2011; Fisher et al. 2012; Teale and Miller 2012; Birks et al. 2019), which are essentially the 'last meal' representing a few hours of individual browsing. These techniques offer paleoecological insights that are minimally time-averaged, and at a timescale that may be comparable to modern observations of animal behavior.

Other approaches resolve time periods that are weeks to months in duration. Fisher's (Fisher and Fox 2006; Fisher 2009; 2018) work on incremental growth structures in proboscidean tusk and molar dentin reliably record weekly to monthly behaviors. The resolution 
100 of these methods may even include short-term, often periodic, life history events, such as

101 reproductive competition (musth) and calving. Other researchers (Hoppe et al. 1999; Metcalfe

102 and Longstaffe 2012; 2014; Pérez-Crespo et al. 2016) have explored incremental growth trends

103 in proboscidean tooth enamel. Adult molars form over the course of 10-12 years with an enamel

104 extension rate of $\sim 1 \mathrm{~cm} /$ year in both modern elephants (Uno et al. 2013) and mammoths (Dirks

105 et al. 2012; Metcalfe and Longstaffe 2012) providing the opportunity to understand meso-scale

106 (potentially monthly) changes in diet and behavior.

Finally, some techniques measure animal diet and behavior over much longer scales

108 (years-decades). In humans, bone collagen is replaced at a rate of 1.5-4\% per year (Hedges et al.

109 2007). For equally long-lived proboscidean taxa, this means that stable isotope analyses of bone

110 collagen is essentially sampling a moving average of $\sim 20$ years of animal growth. For younger

111 age groups, this average will be weighted towards time periods of accelerated maturation

112 (adolescence), when collagen is replaced at a much greater rate (Hedges et al. 2007). Tooth

113 enamel can also be sampled at a resolution (i.e., "Bulk" enamel) that averages a year (or more) of

114 growth (Hoppe 2004; Baumann and Crowley 2015), and it is likely that this is the approximate

115 temporal scale that is controlling tooth mesowear (Fortelius and Solounias 2000).

116 Stable isotope studies are an important part of the paleoecological toolkit for

117 understanding Quaternary proboscideans and are capable of resolving animal behavior at

118 multiple timescales. Progressively larger, more complete datasets characterize isotopic studies of

119 Beringian mammoths, where stable carbon and oxygen isotopes in bone collagen and tooth

120 enamel reliably track climate and landscape changes over the late Pleistocene (Bocherens et al.

121 1996; Iacumin et al. 2010; Szpak et al. 2010; Arppe et al. 2019), the place of mammoths in 
122 regional food webs (Fox-Dobbs et al. 2007, 2008), and characteristics of animal growth and

123 maturation (Metcalfe and Longstaffe 2012; Rountrey et al. 2012; El Adli et al. 2017).

125 in temperate North America. From the West Coast (Coltrain et al. 2004; El Adli et al. 2015) to

126 the southwestern (Metcalfe et al. 2011), and eastern US (Koch et al. 1998; Hoppe and Koch

127 2007), isotopic approaches have been very successful in understanding local to regional scale

128 behavior in mammoths and mastodons. Although there have been efforts to understand

129 mammoth and mastodon behaviors in the Midwest at relatively limited geographic scales

130 (Saunders et al. 2010; Baumann and Crowley 2015), there is a need to systematically address

131 long-term isotopic trends throughout the region. In this paper, we approach this problem from a

132 broad regional perspective, leveraging a recently reported radiocarbon $\left({ }^{14} \mathrm{C}\right)$ dataset with

133 associated isotopic data on bone collagen. We also utilize an enamel dataset consisting of both

134 serial bulk and micro-milled mammoth molar enamel samples (C, O, Sr isotope systems).

135 Together, the results of these analyses offer a picture of mammoth and mastodon diets $\left(\delta^{13} \mathrm{C}\right.$,

$\left.136 \delta^{15} \mathrm{~N}\right)$, late Quaternary paleoclimate $\left(\delta^{18} \mathrm{O}\right)$, and animal mobility $\left({ }^{87} \mathrm{Sr} /{ }^{86} \mathrm{Sr}\right)$ that is geographically

137 comprehensive and spans the past 50,000 years.

\section{MATERIALS AND METHODS}

The proboscidean dataset in this study (Figure 1; SM Table 1, SM Table 2, SM Table 3)

140 was acquired with the goal of understanding mammoth and mastodon population dynamics

141 during the late Pleistocene as these taxa approach extinction. Chronological and broad-scale

142 paleoecological implications for this dataset were explored in Widga et al. (2017a) and more

143 recently in Broughton and Weiztel (2018). In this paper we focus on the implications of these 
144 data for the stable isotope ecology of midwestern Proboscidea. We also discuss annual patterns

145 in five serially sampled mammoth teeth spanning the last glacial-interglacial cycle. Finally, we

146 micro-sampled two mammoths from the Jones Spring locality in Hickory Co., MO. Although

147 beyond the range of radiocarbon dating, both samples are associated with well-dated

148 stratigraphic contexts (Haynes 1985). Specimen 305JS77 is an enamel ridge-plate recovered

149 from unit d1 (spring feeder), refitting to an M3 from unit c2 (lower peat). Unit c2 is part of the

150 lower Trolinger formation (Haynes 1985) and can be assigned to Marine Isotope Stage (MIS) 4.

151 Specimen 64JS73 is an enamel ridge-plate from unit e2 (sandy peat) in the upper Trolinger

152 formation (Haynes 1985) and can be assigned to MIS 3. Together, these samples provide dozens

153 of seasonally-calibrated isotopic snapshots representing mammoth behavior from individuals that

154 pre-date the last glacial maximum (LGM).

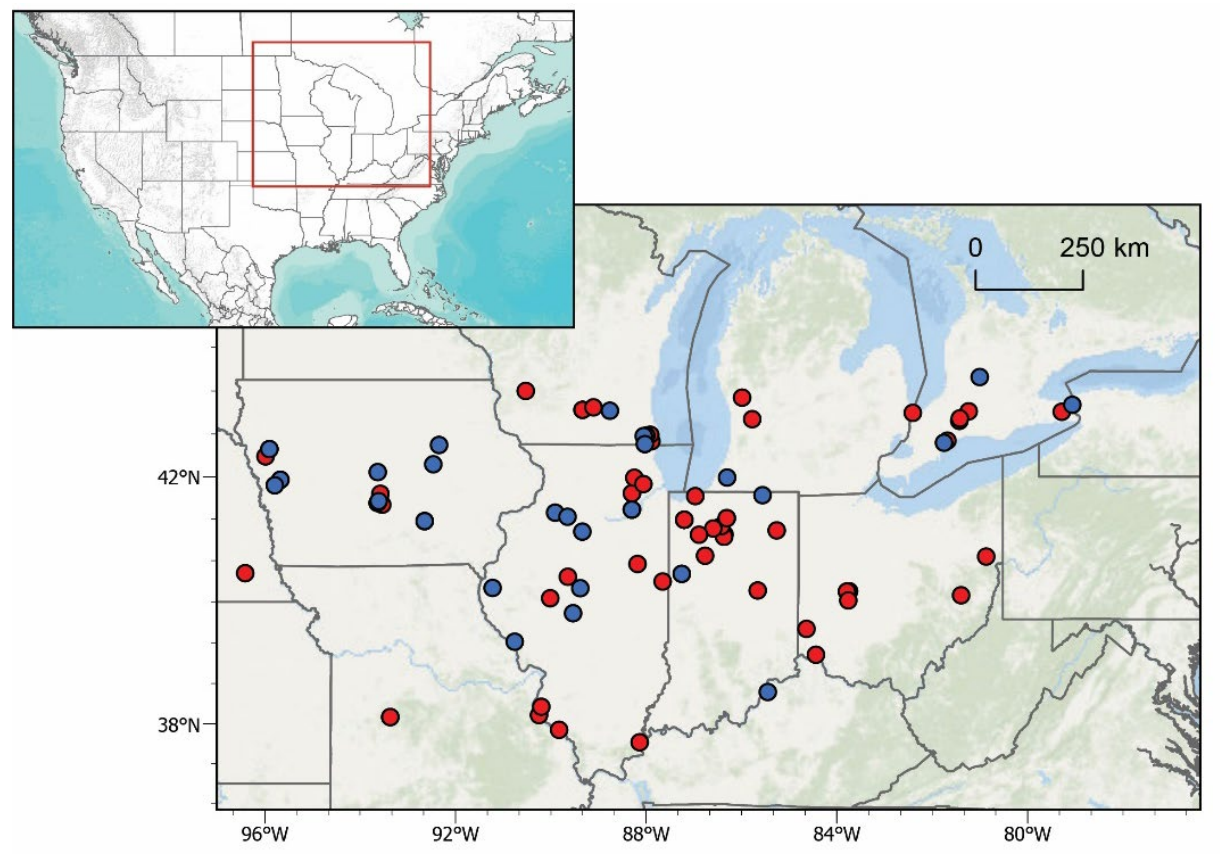

156 Figure 1. Map of dated midwestern mammoths (blue) and mastodons (red) with associated 
Due to extensive late Pleistocene glaciation in the region, this dataset is dominated by samples

162 dating to the LGM or younger (<22 ka). Only 14 out of $93(15 \%)$ localities predate the LGM.

All samples were removed from dense bone, tooth or tusk dentin and submitted to the

164 University of Arizona AMS laboratory. Collagen was prepared using standard acid-base-acid

165 techniques (Brock et al. 2010), its quality evaluated visually, and through ancillary

166 Carbon:Nitrogen (C:N) analyses. Visually, well-preserved collagen had a white, fluffy

167 appearance and $\mathrm{C}: \mathrm{N}$ ratios within the range of modern bones (2.9-3.6) (Tuross et al. 1988).

168 Samples outside of this range were not included in the study. Samples that had the potential to be

169 terminal ages were subjected to additional analyses where the ABA-extracted gelatin was ultra-

170 filtered (UF) through $>30 \mathrm{kD}$ syringe filters to isolate relatively undegraded protein chains

171 (Higham et al. 2006). This fraction was also dated. All radiocarbon ages in this dataset are on

172 collagen from proboscidean bone or tooth dentin and available in Widga et al. (2017a), through

173 the Neotoma Paleoecology Database (www.neotomadb.org) or in SM Table 1. Measured

174 radiocarbon ages were calibrated in Oxcal v4.3 (Bronk Ramsey 2009) using the Intcal13 dataset

175 (Reimer et al. 2013). All stable isotope samples were analyzed on a Finnigan Delta PlusXL

176 continuous-flow gas-ratio mass spectrometer coupled to a Costech elemental analyzer at the

177 University of Arizona. Standardization is based on acetanilide for elemental concentration, NBS-

17822 and USGS-24 for $\delta^{13} \mathrm{C}$, and IAEA-N-1 and IAEA-N-2 for $\delta^{15} \mathrm{~N}$. Isotopic corrections were

179 done using a regression method based on two isotopic standards. The long-term analytical

180 precision (at $1 \sigma$ ) is better than $\pm 0.1 \%$ for $\delta^{13} \mathrm{C}$ and $\pm 0.2 \%$ for $\delta^{15} \mathrm{~N}$. All $\delta^{13} \mathrm{C}$ results are 
181 reported relative to Vienna Pee Dee Belemnite (VPDB) and all $\delta^{15} \mathrm{~N}$ results are reported relative to N-Air. were sampled at two different scales. Serial sampling consisted of milling a series of 5-10 mg

185 samples of enamel powder with a handheld rotary tool equipped with a $1.5 \mathrm{~mm}$ diameter carbide

186 bit along the axis of growth. Sample spacing was $\sim 1$ sample per centimeter of tooth growth.

187 However, given the geometry and timing of enamel maturation (Dirks et al. 2012), these samples 188 at best, approximate an annual scale of dietary and water inputs.

190 movement and behavior (Metcalfe and Longstaffe 2012). For this project, we built a custom

191 micromill capable of in situ, micron-resolution, vertical sampling of a complete mammoth molar.

192 This micromill setup consisted of two Newmark linear stages coupled to a Newmark vertical

193 stage to allow movement in 3-dimensions. These stages were controlled by a Newmark NSC-G

194 3-axis motion controller using GalilTools on a PC. A 4-cm diameter ball joint allowed levelling

195 of a metal (Version 1) or acrylic (Version 2) plate for holding a specimen. The armature for

196 Version 1 consisted of a 1971 Olympus Vanox microscope retrofitted with a stationary Proxxon

$19750 /$ E rotary tool using a $0.5 \mathrm{~mm}$ end mill. Version 2 has replaced this setup with a U-strut

198 armature using a 3D printed drill mount to allow for greater vertical and horizontal movement to

199 accommodate large, organically-shaped specimens. Specimens were stabilized on the mounting

200 plate using heat-flexible thermoplastic cradle affixed to a metal plate with machine screws

201 (Version 1). However, we later developed an acrylic mounting plate method where a mammoth

202 tooth could be sufficiently stabilized using zip ties (Version 2). This micromill was developed to

203 address the challenges of accurately micro-milling large specimens with minimal instrumentation 
costs. Complete plans for this micromill are available under an open hardware license at

Micro-mill sampling resolution was 1 sample per millimeter along the growth axis of the

207 tooth plate (Figure 2). Each sample was milled in $100 \mu$ m-deep passes through the entire

208 thickness of the enamel. The lowest enamel sample (i.e., closest to the enamel-dentin boundary)

209 in the series was used for isotopic analyses to minimize the effects of mineralization and

210 diagenesis on the biological signal (Zazzo et al. 2006). Enamel powder was collected in de-

211 ionized water to; 1) maximize sample recovery, and 2) lubricate the mill. These samples were

212 too small for standard pretreatment of tooth enamel $\mathrm{CO}_{3}$ (Koch et al. 1997). However, paired

213 bulk enamel samples treated with $0.1 \mathrm{~N}$ acetic acid and $2.5 \% \mathrm{NaOCl}$ show results that are the

214 same as untreated bulk samples. Although this technique is both time- and labor- intensive, it is

215 minimally invasive and is capable of sampling enamel growth structures at high resolution.

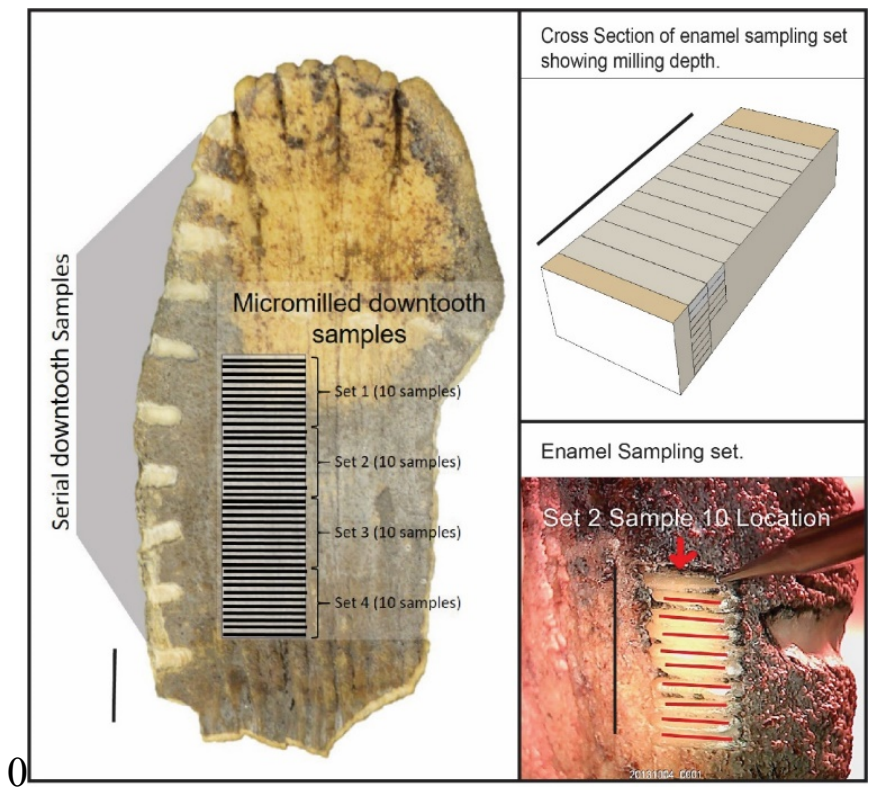


All enamel powder samples were measured in a Finnigan Delta Plus XL mass

220 spectrometer in continuous flow mode connected to a Gas Bench with a CombiPAL autosampler

221 at the Iowa State University Stable Isotope lab, Department of Geological and Atmospheric

222 Sciences. Reference standards (NBS-18, NBS-19) were used for isotopic corrections, and to

223 assign the data to the appropriate isotopic scale. Corrections were done using a regression

224 method using NBS-18 and NBS-19. Isotope results are reported in per mil (\%). The long-term

225 precision (at $1 \sigma$ ) of the mass spectrometer is $\pm 0.09 \%$ for $\delta^{18} \mathrm{O}$ and $\pm 0.06 \%$ for $\delta^{13} \mathrm{C}$,

226 respectively, and precision is not compromised with small carbonate samples $(\sim 150$

227 micrograms). Both $\delta^{13} \mathrm{C}$ and $\delta^{18} \mathrm{O}$ are reported VPDB.

$229\left(\delta^{13} \mathrm{C}_{\text {diet }}\right)$ (Daniel Bryant and Froelich 1995).

$$
\delta^{18} \mathrm{O} \mathrm{SMOW}=\left(1.03086 * \delta^{18} \mathrm{O} \mathrm{VPDB}\right)+30.86
$$

232 The $\delta^{18} \mathrm{O}$ of enamel phosphate $\left(\delta^{18} \mathrm{O}_{\mathrm{p}}\right)$ for these samples was calculated from the $\delta^{18} \mathrm{O}$ of enamel 233 carbonate $\left(\delta^{18} \mathrm{O}_{\mathrm{c}}\right)($ Fox and Fisher 2001)

$$
\delta^{18} \mathrm{O}_{\mathrm{p}}=\left(\delta^{18} \mathrm{O}_{\mathrm{c}} / 1.106\right)-4.7288
$$

235 Estimates of body water $\delta^{18} \mathrm{O}\left(\delta^{18} \mathrm{O}_{\mathrm{w}}\right)$ were calculated following Dauxe et al. (2008)

$$
\delta^{18} \mathrm{O}_{\mathrm{w}}=\left(1.54 * \delta^{18} \mathrm{O}_{\mathrm{p}}\right)-33.72 \text { (Dauxe et al. 2008) }
$$


enamel powder samples were split from the light isotope samples described above, and represent

240 the same portions of mammoth teeth. Each $\sim 5 \mathrm{mg}$ sample of powder was leached in $500 \mu \mathrm{L} 0.1$

$241 \mathrm{~N}$ acetic acid for four hours to remove diagenetic calcite and rinsed 3 times with deionized water

242 (centrifuging between each rinse). In the micromilled series, small sample sizes prevented $\mathrm{Sr}$

243 analyses from being performed on the same samples as $\delta^{13} \mathrm{C}$ and $\delta^{18} \mathrm{O}$ analyses. Therefore, $\mathrm{Sr}$

244 from these growth series was analyzed opportunistically, or at the scale of 1 sample every $2 \mathrm{~mm}$.

All enamel samples were then dissolved in $7.5 \mathrm{~N} \mathrm{HNO}_{3}$ and the Sr eluted through ion-

247 Geochemistry Laboratory. ${ }^{87} \mathrm{Sr} /{ }^{86} \mathrm{Sr}$ ratios were measured on a Thermal Ionization Mass

248 Spectrometer (TIMS), an automated VG Sector 54, 8-collector system with a 20-sample turret, at

249 the University of Kansas Isotope Geochemistry laboratory. Isotope ratios were adjusted to

250 correspond to a value of 0.71250 on NBS-987 for ${ }^{87} \mathrm{Sr} /{ }^{86} \mathrm{Sr}$. We also assumed a value of ${ }^{86} \mathrm{Sr} /{ }^{88} \mathrm{Sr}$

251 of 0.1194 to correct for fractionation.

The distribution of ${ }^{87} \mathrm{Sr} /{ }^{86} \mathrm{Sr}$ values in vegetation across the surface of the midcontinent is

253 determined by the values of soil parent material. In a large part of this region, surface materials

254 are composed of allochthonous Quaternary deposits such as loess, alluvium, and glacial debris.

255 Therefore continent-scale Sr isoscape models derived from bedrock or water (Bataille and

256 Bowen 2012) are not ideal for understanding first order variability in midwestern ${ }^{87} \mathrm{Sr} /{ }^{86} \mathrm{Sr}$. For

257 these reasons, Widga et al. (2017) proposed a Sr isoscape for the Midwest based on surface

258 vegetation. At a regional scale, these trends in vegetation ${ }^{87} \mathrm{Sr} /{ }^{86} \mathrm{Sr}$ reflect the Quaternary history

259 of the region, and are consistent with other, empirically derived, patterns in Sr isotope

260 distribution from the area (Slater et al. 2014; Hedman et al. 2018). Sr isotope values in mammoth 
261

262

263

264

265

266

267

268

269

270

271

272

273

274

275

276

277

278

279

280

281

282

enamel are compared to a ${ }^{87} \mathrm{Sr} /{ }^{86} \mathrm{Sr}$ isoscape constructed from the combined datasets of Widga et al. (2017b) and Hedman et al. (2009), and Hedman et al. (2018).

\section{RESULTS}

The collagen of 54 mastodons and 22 mammoths was analyzed for $\delta^{13} \mathrm{C}_{\text {coll }}$ and $\delta^{15} \mathrm{~N}_{\text {coll }}$ (Table 2). Three mastodons have ${ }^{14} \mathrm{C}$ ages that place them beyond the range of radiocarbon dating, and the youngest mastodons date to the early part of the Younger Dryas, shortly before extinction. Despite being well-represented prior to the LGM and during deglaciation (i.e., Oldest Dryas, Bølling, Allerød, Younger Dryas), this dataset lacks mastodons from the study region during the coldest parts of the LGM. Mammoths are present in this dataset from 40 ka until their extinction in the region during the late Allerød.

Visually, there is substantial amounts of overlap in the $\delta^{13} \mathrm{C}_{\text {coll }}$ and $\delta^{15} \mathrm{~N}_{\text {coll }}$ of mammoths and mastodons through the duration of the dataset (Figure 3, Table 2). Both taxa show average $\delta^{13} \mathrm{C}_{\text {coll }}$ values around $-20 \%$, consistent with a diet dominated by C3 trees, shrubs, and/or coolseason grasses. This is broadly consistent with variable, but shared diets during time periods when both taxa occupied the region. The average $\delta^{13} \mathrm{C}_{\text {coll }}$ values for mammoths $(-20.4 \%$ o $)$ is similar to that of mastodons (-21.0\%). The average $\delta^{15} \mathrm{~N}_{\text {coll }}$ of mammoths $(7.5 \%)$ is elevated compared to mastodons $(4.4 \%)$.

However, dietary relationships between taxa are not static through time. Prior to the LGM, both $\delta^{13} \mathrm{C}_{\text {coll }}$ and $\delta^{15} \mathrm{~N}_{\text {coll }}$ are significantly different between mammoths and mastodons $\left(\delta^{13} \mathrm{C}\right.$ t-test; $\mathrm{p}=0.013 ; \delta^{15} \mathrm{~N}$ t-test; $\left.\mathrm{p}=0.010\right)$. During the Oldest Dryas the $\delta^{13} \mathrm{C}_{\text {coll }}$ of both taxa is very similar, although $\delta^{15} \mathrm{~N}_{\text {coll }}$ between mammoths and mastodons remains distinct (t-test; $\mathrm{p}=0.012$ ). During the Allerød, $\delta^{13} \mathrm{C}_{\text {coll }}$ and $\delta^{15} \mathrm{~N}_{\text {coll }}$ between taxa are indistinguishable. 
The $\delta^{13} \mathrm{C}_{\text {coll }}$ signature of mastodon diets changes little throughout the last $50 \mathrm{ka}$. Despite a

284 noticeable absence of mastodon material during the height of the LGM, the only significant shift

285 in the $\delta^{13} \mathrm{C}_{\text {coll }}$ of mastodon diets occurs between the Bølling and the Allerød (t-test; $\left.\mathrm{p}=0.008\right)$.

286 Mastodon $\delta^{15} \mathrm{~N}_{\text {coll }}$ values fall clearly into two groups, those that date prior to the LGM,

287 and those that post-date the LGM. Mastodon $\delta^{15} \mathrm{~N}_{\text {coll }}$ values are significantly higher in pre-LGM

288 samples than in samples dating to the Younger Dryas (t-test; $p=0.010)$, Allerød (t-test; $p=0.017)$,

289 and Bølling (t-test; $\mathrm{p}<0.000)$. Of note is a group of mastodons that show lower $\delta^{15} \mathrm{~N}_{\text {coll }}$ values

290 during the Oldest Dryas, Bølling, Allerød, and Younger Dryas, when the average $\delta^{15} \mathrm{~N}_{\text {coll }}$ values

291 decrease to values $<5 \%$. A similar shift is not evident in mammoths at this time.

292 Mammoth $\delta^{13} \mathrm{C}_{\text {coll }}$ during MIS 3 is significantly different from mammoths dating to LGM

293 II (t-test; $p=0.008)$ or the Oldest Dryas ( $t$-test; $p=0.005)$. There are no significant differences in

294 mammoth $\delta^{15} \mathrm{~N}_{\text {coll }}$ between different time periods. 


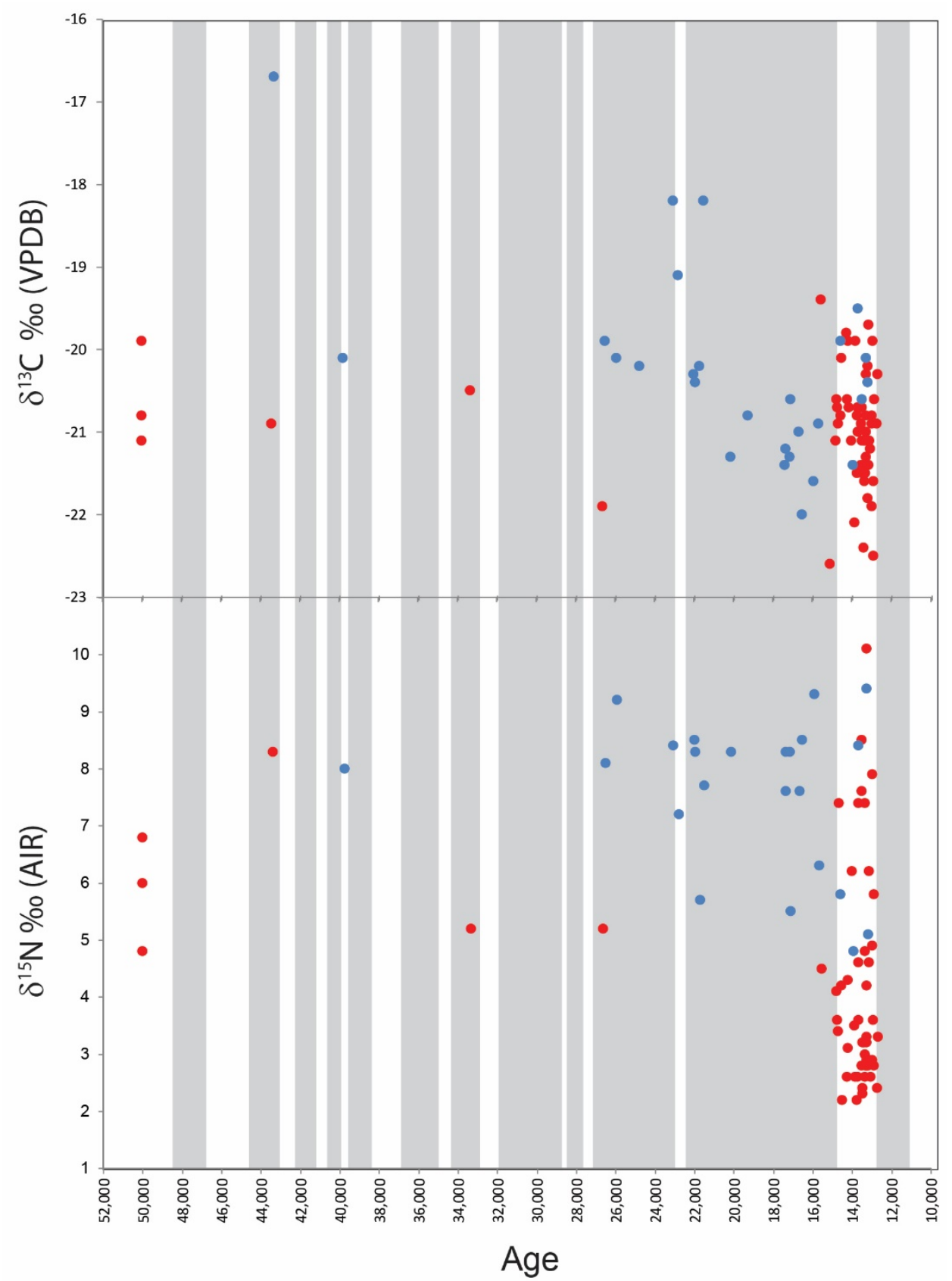


Table 2. Mastodon and Mammoth collagen stable isotope values, by chronozone. $\delta^{13} \mathrm{C}$ values reported as \%o relative to VPDB. $\delta^{15} \mathrm{~N}$ values reported as \%o relative to Air.

\begin{tabular}{|l|l|l|l|l|}
\hline Taxon & Chronozone & $\mathrm{N}$ & $\overline{\mathrm{x}} \delta^{13} \mathrm{C}(\mathrm{s} . \mathrm{d})$ & $\overline{\mathrm{x}} \delta^{15} \mathrm{~N}(\mathrm{~s} . \mathrm{d})$ \\
\hline Mammut & Younger Dryas $(12.9-11.5 \mathrm{ka})$ & 2 & $-20.6(0.4)$ & $2.9(0.6)$ \\
\cline { 2 - 5 } & Allerød $(14.0-12.9 \mathrm{ka})$ & 35 & $-21.1(0.6)$ & $4.2(2.1)$ \\
\cline { 2 - 5 } & Bølling $(14.6-14.0 \mathrm{ka})$ & 6 & $-20.4(0.5)$ & $3.8(1.5)$ \\
\cline { 2 - 5 } & Oldest Dryas $(14.6-17.4 \mathrm{ka})$ & 5 & $-20.5(0.7)$ & $4.6(1.6)$ \\
\cline { 2 - 5 } & LGM II $(17.4-20.9 \mathrm{ka})$ & 0 & & \\
\cline { 2 - 5 } & LGM I $(20.9-22.9 \mathrm{ka})$ & 0 & & \\
\cline { 2 - 5 } & Pre-LGM $(>22.9 \mathrm{ka})$ & 6 & $-20.9(0.7)$ & $6.1(1.3)$ \\
\cline { 2 - 5 } & Average & 54 & $-21.0(0.7)$ & $4.4(2.0)$ \\
\hline & Allerød $(14.0-12.9 \mathrm{ka})$ & 3 & $-20.6(0.9)$ & $6.1(2.0)$ \\
\cline { 2 - 5 } & Bølling $(14.6-14.0 \mathrm{ka})$ & 1 & -19.9 & 5.8 \\
\cline { 2 - 5 } & Oldest Dryas $(14.6-17.4 \mathrm{ka})$ & 4 & $-21.4(0.5)$ & $7.9(1.3)$ \\
\cline { 2 - 5 } & LGM II $(17.4-20.9 \mathrm{ka})$ & 4 & $-21.1(0.4)$ & $7.4(1.3)$ \\
\cline { 2 - 5 } & LGM I $(20.9-22.9 \mathrm{ka})$ & 5 & $-20.1(1.1)$ & $7.6(1.2)$ \\
\cline { 2 - 5 } & Pre-LGM $(>22.9 \mathrm{ka})$ & 5 & $-19.6(0.8)$ & $8.2(0.7)$ \\
\cline { 2 - 5 } & Average & 22 & $-20.4(1.0)$ & $7.5(1.3)$ \\
\hline
\end{tabular}

$* \overline{\mathrm{x}}=$ mean; s.d. $=$ standard deviation

All serial enamel series were between 9 and $16 \mathrm{~cm}$ in length and represent multiple years.

Stable oxygen isotopes of three MIS 2 mammoths (Principia College, Brookings, Schaeffer)

overlap significantly, while MIS 4 (234JS75) and MIS 5e (232JS77) mammoths from Jones

Spring show elevated values indicative of warmer conditions (Table 3; Figure 4). The variance in serially sampled MIS 2 mammoths (average amp. =2.5\%) was not significantly different from

the series from Jones Spring, dating to MIS $4(\mathrm{amp} .=2.9 \%)(F-t e s t ; p=0.320)$. However, the MIS 5e mammoth from Jones Spring has a smaller amplitude (amp. =1.1\%o) compared to both the MIS 4 mammoth (F-test; $p=0.003$ ) and the three MIS 2 mammoths (F-test; $p<0.000)$. Strontium isotope ratios of this animal indicates a home range on older surfaces of the Ozarks, throughout tooth formation, with a period of relatively elevated ${ }^{87} \mathrm{Sr} /{ }^{86} \mathrm{Sr}$ values also corresponding to low $\delta^{18} \mathrm{O}$ values. 
317 Table 3. Summary of serial and micro-sampled Mammuthus tooth enamel: $\delta^{13} \mathrm{C}, \delta^{18} \mathrm{O}$, and $318 \quad{ }^{87} \mathrm{Sr} /{ }^{86} \mathrm{Sr}$.

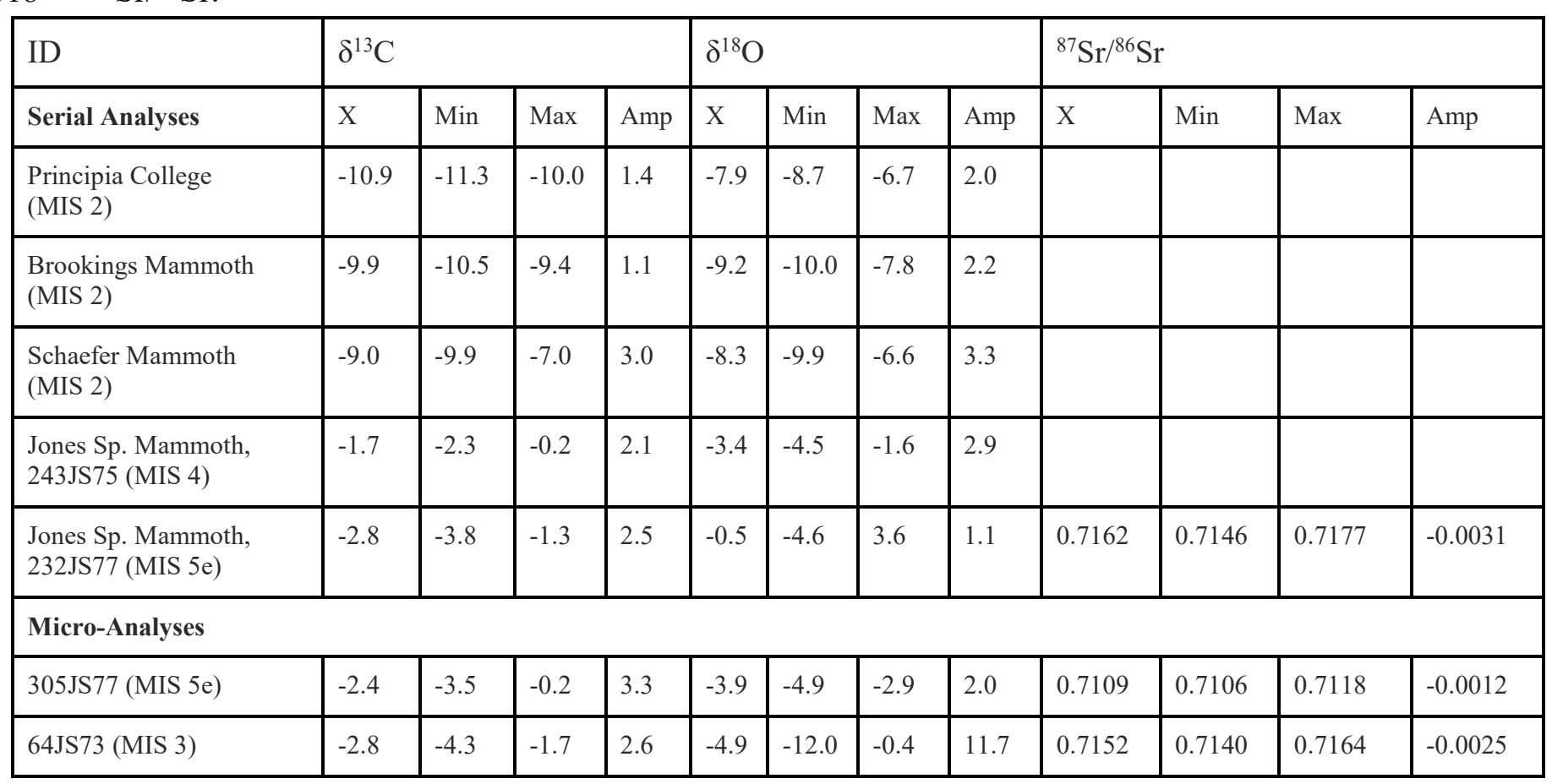


bioRxiv preprint doi: https://doi.org/10.1101/2020.01.08.896647; this version posted May 28, 2020. The copyright holder for this preprint (which

was not certified by peer review) is the author/funder, who has granted bioRxiv a license to display the preprint in perpetuity. It is made available under aCC-BY-NC-ND 4.0 International license.

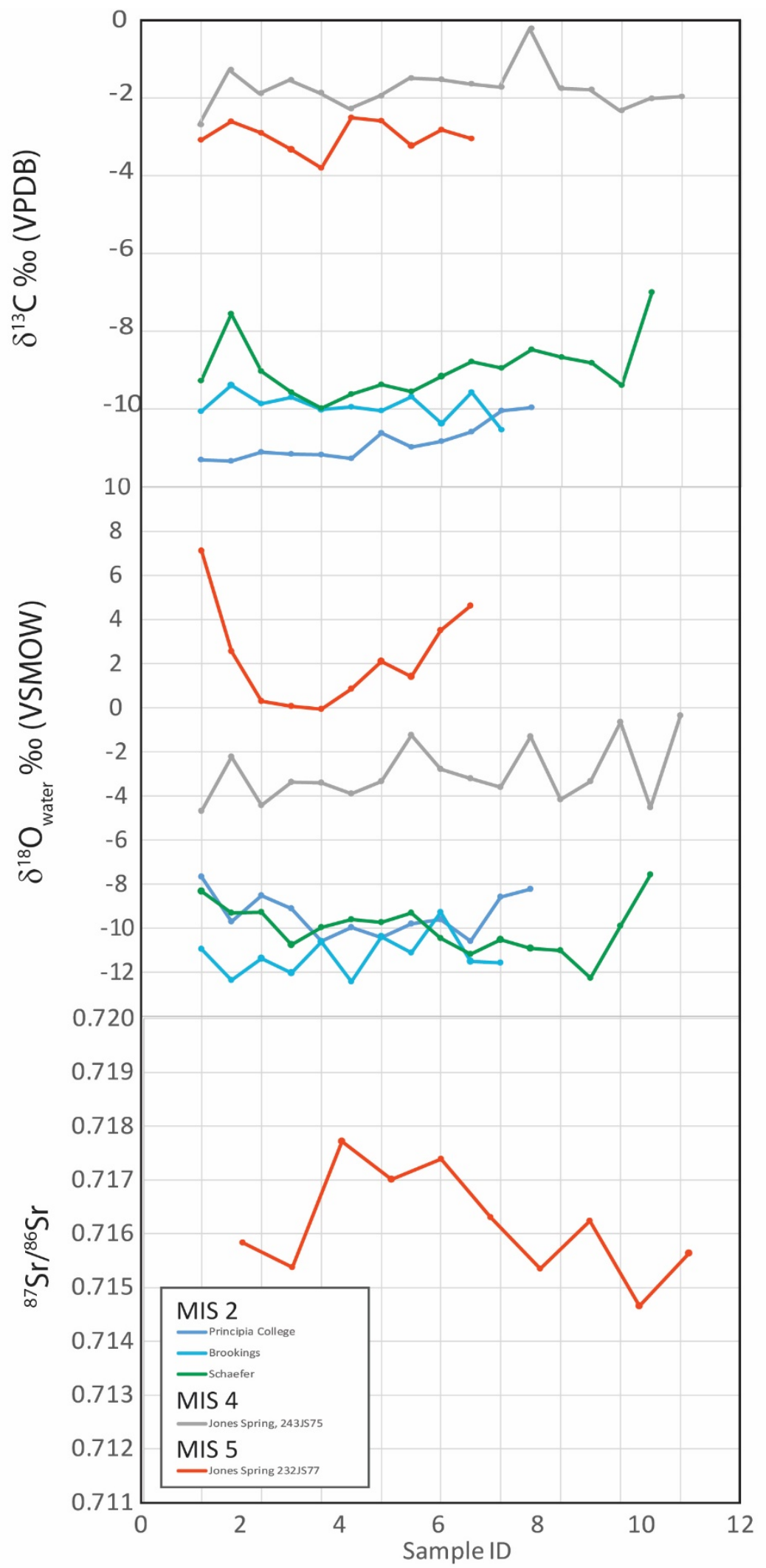

Figure 4. Time series, serial enamel $\delta^{13} \mathrm{C}, \delta^{18} \mathrm{O},{ }^{87} \mathrm{Sr} /{ }^{86} \mathrm{Sr}$. 
bioRxiv preprint doi: https://doi.org/10.1101/2020.01.08.896647; this version posted May 28, 2020. The copyright holder for this preprint (which

was not certified by peer review) is the author/funder, who has granted bioRxiv a license to display the preprint in perpetuity. It is made available under aCC-BY-NC-ND 4.0 International license.

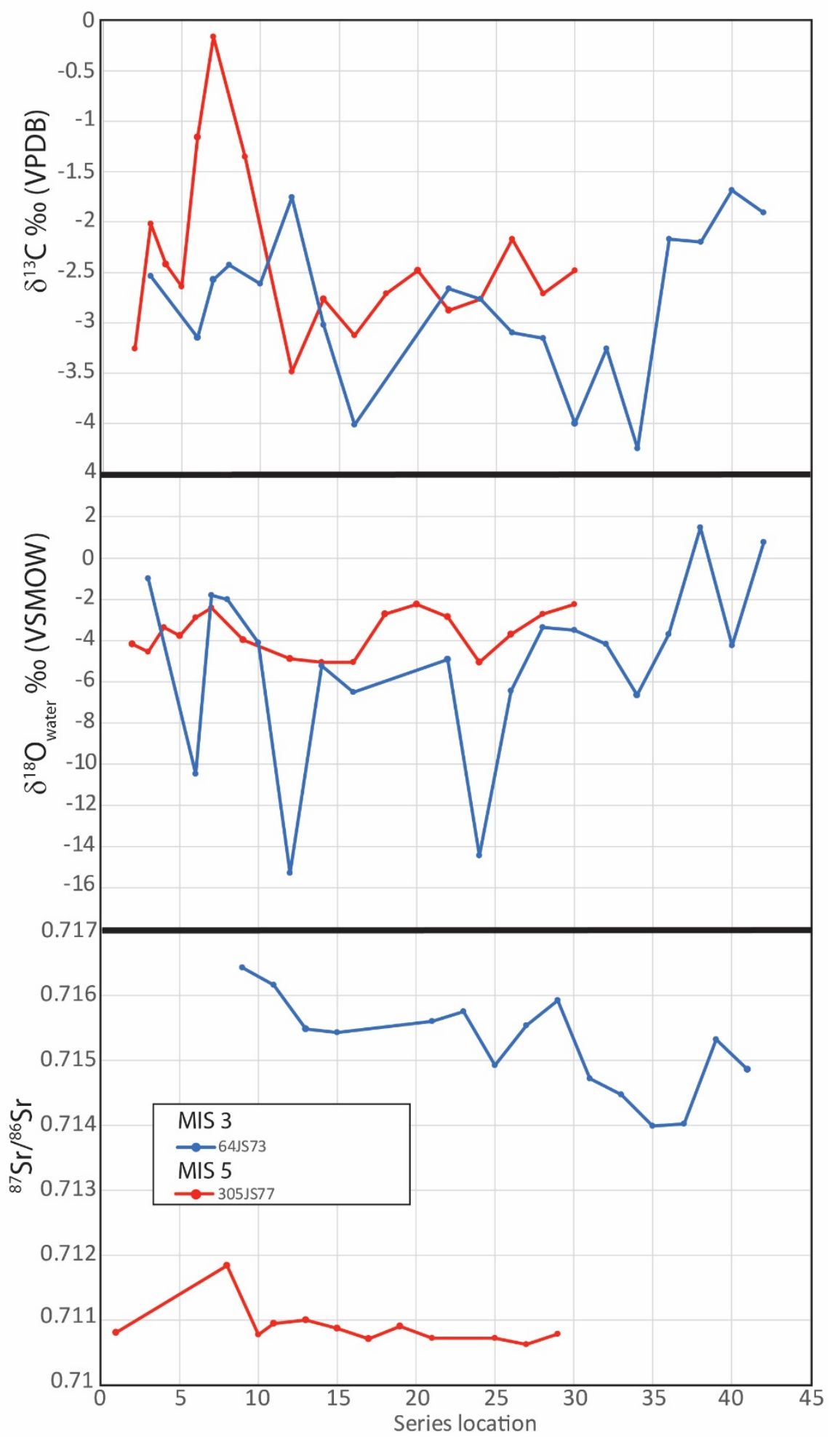

Figure 5. Time series, micro-sampled enamel $\delta^{13} \mathrm{C}, \delta^{18} \mathrm{O},{ }^{87} \mathrm{Sr} /{ }^{86} \mathrm{Sr}$. Both specimens are 
330 of seasonal temperature changes in ingested water. These excursions are relatively short-lived

331 and extreme. Seasonal variation in enamel growth rate and maturation may account for the

332 perceived short length of these periods. Maximum $\delta^{18} \mathrm{O}$ values in both mammoths are similar

333 however; the MIS 5e mammoth lacks these negative excursions and exhibits values that are more 334 complacent through the length of the tooth.

336 throughout the year. However, deep dips in the $\delta^{18} \mathrm{O}$ series of the MIS 3 molar also correspond to 337 at least two temporary peaks in the $\delta^{13} \mathrm{C}$ series.

$338 \quad \mathrm{The}{ }^{87} \mathrm{Sr} /{ }^{86} \mathrm{Sr}$ isotope series from both animals demonstrate an adherence to separate

339 home ranges. The MIS 5e mammoth shows values similar to bedrock units outcropping locally

340 in central-western Missouri and neighboring areas of Kansas and Oklahoma. The MIS 3

341 mammoth, however, had a home range across rock units with much higher ${ }^{87} \mathrm{Sr} /{ }^{86} \mathrm{Sr}$ values. The

342 home ranges for these animals do not overlap, despite their recovery from different strata within

343 the same locality. 


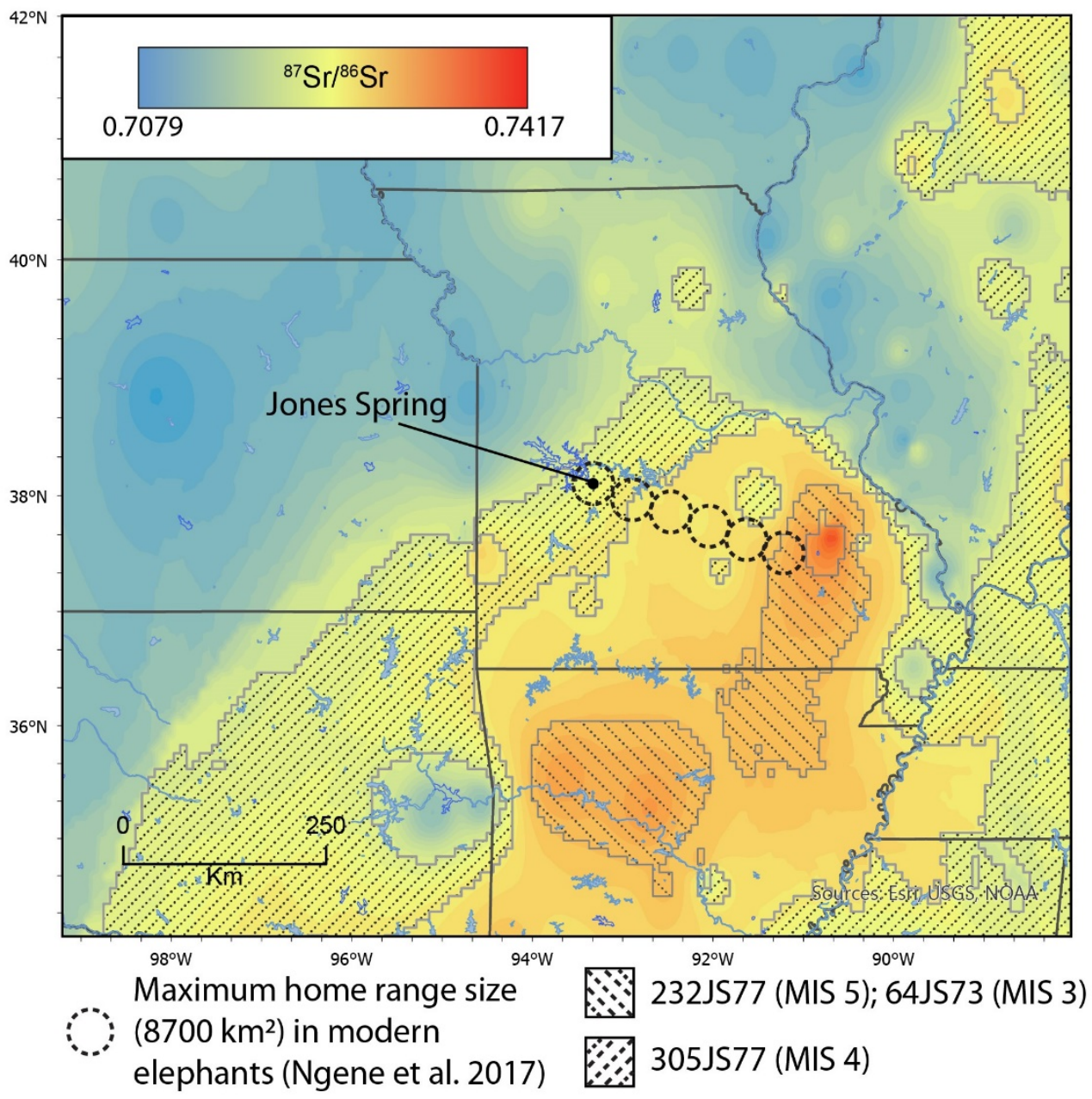

345 Figure 6. Mobility in mammoths from Jones Spring, Hickory Co., MO. Hatched areas indicate

346 the range of ${ }^{87} \mathrm{Sr} /{ }^{86} \mathrm{Sr}$ values from mammoth molar ridge-plates. One mammoth (305JS77)

347 exhibits local values. Two separate mammoths (232JS77, 64JS73) exhibit Sr values suggesting

$348>200 \mathrm{~km}$ movement from the central core of the Ozark uplift. This implies movement over

349 multiple years that is at least six times larger than the maximum home range size documented in 350 modern elephants (Netosha National Park, Namibia). Basemap isoscape data from Widga et al. 


\section{DISCUSSION}

Despite overall similar isotopic values in mammoths and mastodons throughout the

354 period of this study, underlying nuances are informative to regional changes in niche structure

355 and climate. The absence of mastodons during the coldest parts of the LGM suggests that

356 Mammut were, at least to some degree, sensitive to colder climates and adjusted its range

357 accordingly.

358 Comparisons between co-eval mammoths and mastodons indicate a gradual collapse of

359 niche structure. Prior to MIS $2, \delta^{13} \mathrm{C}_{\text {coll }}$ and $\delta^{15} \mathrm{~N}_{\text {coll }}$ values between taxa were significantly

360 different. By the end of the Allerød, mammoth and mastodon diets were isotopically

361 indistinguishable.

Through time, there was no significant change in the $\delta^{13} \mathrm{C}_{\text {coll }}$ of mastodons. Although

363 average mammoth $\delta^{13} \mathrm{C}_{\text {coll }}$ in the region during the latter part of the LGM was slightly more

364 negative than other time periods, this is not a marked shift and may be a function of decreased

365 pCO2 during that time (Schubert and Jahren 2015). Globally, Siberian and European mammoths

366 exhibit a similar range of $\delta^{13} \mathrm{C}_{\text {coll }}$ values (Iacumin et al. 2010; Szpak et al. 2010; Arppe et al.

367 2019; Schwartz-Narbonne et al. 2019).

368 In both taxa, mean $\delta^{15} \mathrm{~N}_{\text {coll }}$ decreases slightly throughout the sequence, however, the

369 minimum $\delta^{15} \mathrm{~N}$ values for mastodons during the Bølling, Allerød, and Younger Dryas are

370 significantly lower than earlier mastodons. The anomalously low values of these late mastodons

371 are also shared with other published mastodon values in the Great Lakes region (Metcalfe et al.

372 2013). They are also significantly lower than contemporary midwestern, Eurasian or Beringean

373 mammoths (with some exceptions, Drucker et al. 2018). The timing of these low, mastodon

$374 \delta^{15} \mathrm{~N}_{\text {coll }}$ values correspond to regionally low $\delta^{15} \mathrm{~N}_{\text {coll }}$ values in the bone collagen of non- 
375

376

377

378

379

380

381

382

383

384

385

386

387

proboscidean taxa from European late Quaternary contexts (Drucker et al., 2009; Richards and Hedges, 2003; Rabanus-Wallace et al., 2017; Stevens et al., 2008) suggesting broad changes in global climate may have had cascading impacts in the $\mathrm{N}$ budget of local ecosystems.

However, understanding in more detail how climate might have affected $\mathrm{N}$ cycling in midwestern ecosystems remains unclear. Flux in soil and plant $\mathrm{N}$ may be a function of plantbased $\mathrm{N}_{2}$ fixation (Shearer and Kohl 1993), rooting depth (Schulze et al. 1994), N loss related to climate factors (Austin and Vitousek 1998; Handley and Raven 1992), microbial activity, or mycorrhizal colonization (Hobbie et al. 2000; Michelsen et al. 1998;). Furthermore, the role of large herbivore populations in N flux may be significant (Frank et al. 2004). In N limited environments such as tundra, terrestrial plants may receive relatively more $\mathrm{N}$ from inorganic sources. Boreal forests like those of the Midwest during the Bølling and Allerød, however, exhibit relatively greater biological productivity, so plant shoots are more likely to take in volatized ammonia (low $\left.\delta^{15} \mathrm{~N}\right)$ from organic sources such as urea (Fujiyoshi et al. 2017).

At this time, it is difficult to distinguish which (if any) of these factors had an impact on late Quaternary mastodon $\delta^{15} \mathrm{~N}_{\text {coll }}$ values. Although there is a wide range in $\delta^{15} \mathrm{~N}_{\text {coll }}$ of mammoths

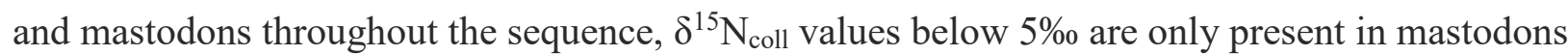
during post-LGM deglaciation in the lower Great Lakes (39-43 deg. latitude), throughout an area suggested to be vegetated by a disharmonius flora dominated by Black Ash and Spruce (Gonzales and Grimm 2009; Gill et al. 2009) (Figure 7). The low $\delta^{15} \mathrm{~N}_{\text {coll values suggest that }}$ these mastodons occupied an undefined, local-scale, dietary niche that was not shared by contemporary mammoths, or by earlier mastodons. Previous research has suggested that the Bølling-Allerød may have been a time of high mastodon populations in the Great Lakes region (Widga et al. 2017a). The concentration of mastodons around water sources may have had an 
impact on the $\delta^{15} \mathrm{~N}$ of browsed plants due to increased contributions of herbivore urea. sources, including urea from herbivores.

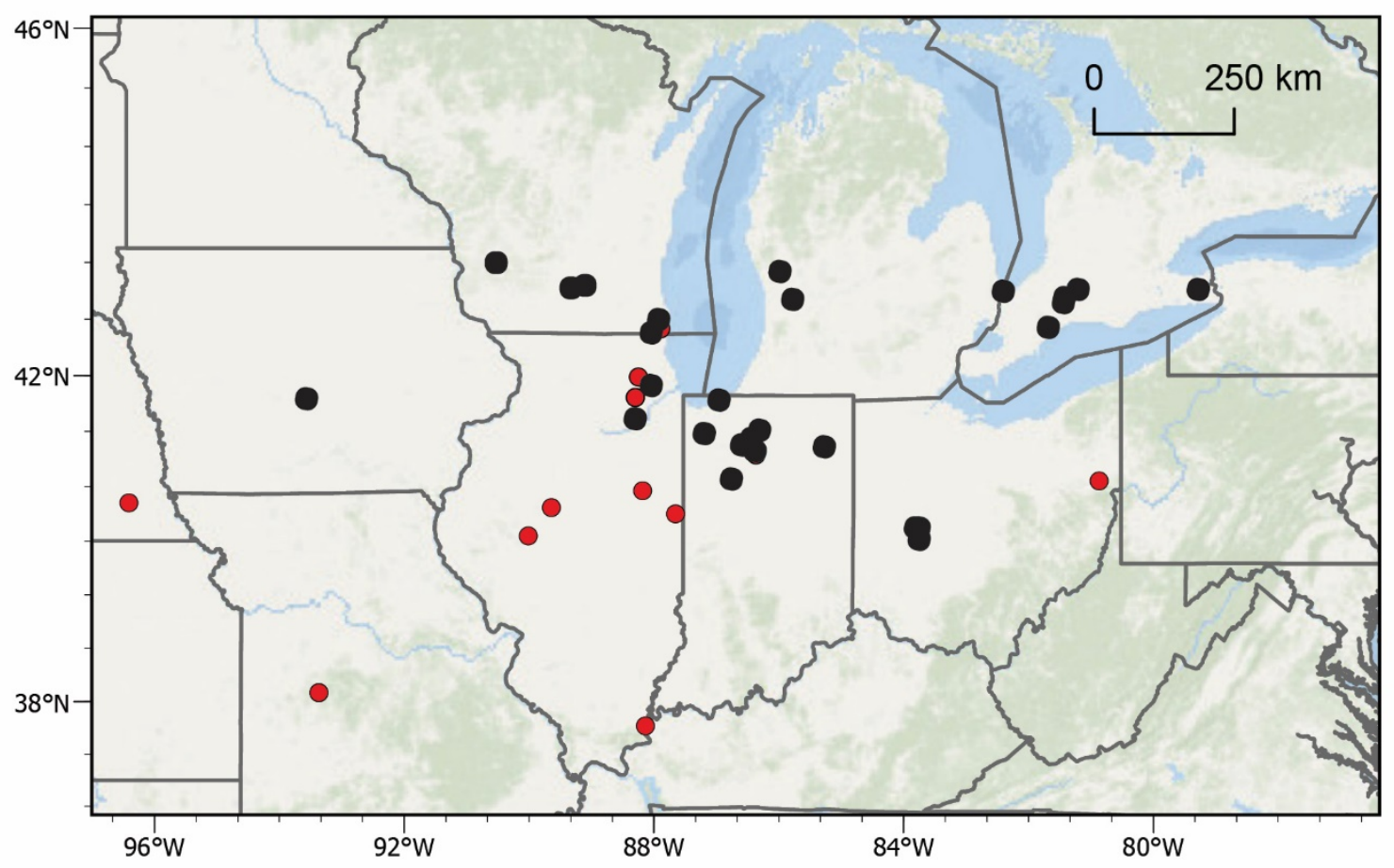

Figure 7. Mastodon distribution during the Bølling-Allerød. Black circles indicate mastodon

$$
\delta^{15} \mathrm{~N}_{\text {coll }}<5 \% \text {. Red circles represent mastodons with } \delta^{15} \mathrm{~N}_{\text {coll }}>5 \% \text {. }
$$

\section{$\underline{\text { Life Histories of midwestern Mammoths }}$}

407 or tusk dentin, we can reconstruct longitudinal life histories that reflect the landscape 
412 individual (Figure 4). Less negative $\delta^{13} \mathrm{C}$ and $\delta^{18} \mathrm{O}$ values in the last forming samples of the

413 Schaeffer mammoth suggest a change in that animal's life history in the year before death. This

414 change could be explained by local environmental changes resulting in nutritional stress.

415 Two mammoths from the Jones Spring site in southwest Missouri provide a pre-LGM

416 perspective on landscapes that mammoths occupied (Figure 4). A tooth plate dating to MIS 5e

417 from Jones Spring has less negative $\delta^{18} \mathrm{O}$ and $\delta^{13} \mathrm{C}$ values compared to the MIS 2 samples. This

418 indicates warmer overall conditions and a diet that incorporated more $\mathrm{C} 4$ grasses throughout

419 multiple years. Pollen from the same stratigraphic units further suggest that southwestern

420 Missouri during MIS 5e was dominated by Pinus (no Picea) with a significant non-arboreal

421 component (King 1973). Importantly, Sr isotopes from this tooth indicate that while this tooth

422 was forming, the animal was foraging across surfaces that are more radiogenic than local values.

423 The nearest area with ${ }^{87} \mathrm{Sr} /{ }^{86} \mathrm{Sr}$ values $>0.7140$ is the central Ozark uplift to the east of Jones

424 Spring (Figure 6). The wide amplitude of $\delta^{18} \mathrm{O}$ values throughout the length of this tooth,

425 combined with the Sr isotope data suggesting adherence to the central Ozark uplift suggest

426 relatively broad shifts in annual water availability and/or that this animal utilized a variety of

427 water sources, including surface sources and freshwater springs.

429 samples and the MIS 5e sample, along with $\delta^{13} \mathrm{C}$ values that indicate more $\mathrm{C} 4$ consumption than

430 MIS 2 samples (Figure 4). This mammoth occupied a cooler environment than the MIS 5e

431 mammoth, but significantly warmer than the late Pleistocene mammoths in the MIS 2 group.

433 in each animal illustrates different life histories (Figure 5). The MIS 4 mammoth occupied the

434 western Ozarks as indicated by ${ }^{87} \mathrm{Sr} /{ }^{86} \mathrm{Sr}$ values deposited throughout the development of the 
sampled portion of the tooth. It occupied a landscape where $\mathrm{C} 4$ vegetation was common, with mild winter temperatures. The MIS 3 mammoth from Jones Spring occupied the central core of

437 the Ozark uplift indicated by ${ }^{87} \mathrm{Sr} /{ }^{86} \mathrm{Sr}$ values deposited during the formation of the sampled

438 tooth. However, between the cessation of enamel formation and death, this animal moved 200

$439 \mathrm{~km}$ to the western Ozarks where it was preserved in the Jones Spring deposits. The $\delta^{18} \mathrm{O}$ series of

440 this animal suggests greater seasonality during MIS 3 compared to MIS 5e, with deep negative

441 excursions during the cold season. It also had a diet composed primarily of C4 vegetation.

These results suggest a broadly similar geographic scale of landscape-use in late

443 Quaternary mammoths in the Midwest to mammoths in the Great Plains and Florida (Esker et al.

444 2019; Hoppe et al. 1999; Hoppe 2004). Overall, mammoths from both regions do not engage in

445 significant seasonal migrations, but can move greater distances at annual to decadal time-scales.

446 Further, although $\delta^{13} \mathrm{C}_{\text {coll }}$ values in mammoths clearly suggest a niche that, at times, included C3-

447 rich diets in a region that was dominated by forest, not grasslands, both Jones Spring mammoths

448 were mixed feeders with C4 grasses making up a significant part of their diet. The individual life

449 histories of these mammoths are highly variable, underscoring the need to control for individual

450 mobility in stable isotope studies of large herbivore taxa.

\section{$\underline{\text { Testing scenarios of late Pleistocene Proboscidean population dynamics }}$}

Can this stable isotope dataset illuminate trends in late Proboscidean population

453 dynamics during deglaciation in the Midwest? It is possible that the shift in $\delta^{15} \mathrm{~N}$ represents the

454 colonization of a novel ecological niche that also coincides with climate and vegetational

455 changes at the beginning of the Bølling-Allerød. However, it is unclear what this niche might be.

456 Stable isotopes alone do not adequately define this niche space, and further paleobotanical work

457 is necessary. Drucker et al. (2018) also noted anomalously low $\delta^{15} \mathrm{~N}$ values in LGM mammoths 
from Mezyhrich in central Europe, and attributed this pattern to a large, but unspecific, shift in

459 dietary niche. This is counter-intuitive in warming landscapes of the Midwest since boreal forests

460 typically have increased amounts of $\mathrm{N}$ fixing microbes relative to tundra environments, thus

461 increasing the $\delta^{15} \mathrm{~N}$ in forage, overall.

462

Some studies have suggested that the growth rate of an individual is inversely correlated

463 with $\delta^{15} \mathrm{~N}$ (Warinner and Tuross 2010). This would be consistent with some scenarios of late

464 Pleistocene mastodon population dynamics. Fisher (Fisher 2009; 2018) suggests that predator

465 pressure from Paleoindian groups who were megafaunal specialists would have caused

466 mastodons to mature at a younger age. A decrease in the age at weaning would mean a shorter

467 period of nursing-related, elevated dietary $\delta^{15} \mathrm{~N}$ in young mastodons. If this were the case, we

468 would expect an overall decrease in $\delta^{15} \mathrm{~N}$ of bone collagen in animals in their first and second

469 decade of life. In our dataset, there is no significant change in maximum or mean $\delta^{15} \mathrm{~N}$ in

470 mastodon bone collagen, despite a subset of mastodons that have lower $\delta^{15} \mathrm{~N}$ values. If predator

471 pressure is contributing to faster maturation and shortening the time of nursing, then it is only

472 occurring in some areas. However, even if this were the case in these areas, it is still uncertain

473 what ecological processes might drive an increase in growth rate. Depending on local forage

474 conditions experienced by an animal, an increase in growth rate may be caused by increased

475 predator pressure (Fisher 2009) or a decrease in population density (Wolverton et al. 2009).

477 change in predator avoidance strategies among some mastodon populations (Fiedel et al. 2019).

478 Mastodons may have been attracted to low $\delta^{15} \mathrm{~N}$ areas such as marshes and wetlands as a

479 response to new predators on the landscape (i.e., humans). However, taphonomic modification of

480 late Pleistocene proboscidean materials by humans or other predators is extremely rare in this 
481 dataset (Widga et al. 2017a), so we see this scenario as an unlikely driver of mastodon landscape 482 use.

484 also be rapid, significant, and long-term changes to $\mathrm{N}$ cycle. An influx of $\mathrm{N}$ via urea as would be expected in high-density areas, would cause isotopically heavy plant roots and isotopically light

486 shoots. Under intense grazing pressure, changes to $\mathrm{N}$ contributions change quickly from

487 inorganic soil mineral $\mathrm{N}$ reservoirs to $\mathrm{N}$ from urea (McNaughton et al. 1988; Knapp et al. 1999).

488 Individuals with lower $\delta^{15} \mathrm{~N}_{\text {coll }}$ values during the Allerød lived in areas with high mastodon

489 populations, which may have contributed to isotopically light forage (due to ammonia

490 volitization, Knapp et al. 1999). However, this scenario does not explain why this shift is absent 491 in mammoths during this time.

\section{CONCLUSIONS}

Stable isotopes of proboscidean tissues in the midwestern US illustrate the variability

495 inherent in modern paleoecological analyses. Traditional approaches to understanding animal

496 diets and landscape use through morphology and a reliance on modern analogues is inadequate

497 for understanding paleoecological changes within megafaunal populations, or during times of

498 rapid ecological change such as the late Quaternary.

Stable isotopes from bone collagen of midwestern proboscideans suggest consistently

500 C3-dominated diets over the last $50 \mathrm{ka}$. During the LGM, mammoth diets may have included C3

501 grasses, but the prevalence of C3 flora during the post-LGM period is likely due to a landscape 
502

503

504

505

506

507

508

509

510

511

512

513

514

515

516

517

518

519

520

521

522 Acknowledgements. 'local' stable isotope values.

shift to more forest (Gonzales and Grimm 2009; Saunders et al. 2010) with grasses making up very little of the floral communities in the southern Great Lakes region.

Despite the strong C3-signal in mammoth and mastodon diets during this period, the range of dietary flexibility and the degree of overlap between these two taxa is striking. The isotopically defined dietary niche of mammoths and mastodons show increasing overlap as they approach extinction. Niche overlap is also supported by assemblages where both taxa co-occur

(Saunders et al. 2010; Widga et al. 2017a). However, there are exceptions to this pattern and some late mastodons exhibit low $\delta^{15} \mathrm{~N}$ values that may indicate the evolution and occupation of a new dietary niche, physiological responses to late Pleistocene ecological changes, or some other process acting on late mastodon populations.

Further resolution of mammoth and mastodon life histories are gleaned from stable isotopes in tooth enamel. $\delta^{13} \mathrm{C}$ and $\delta^{18} \mathrm{O}$ generally track climate and landscape changes experienced during tooth formation. MIS 2 mammoths are broadly similar in their isotopic life histories and illustrate relative homogeneity of landscape conditions across the Midwest at this time. Micro-sampled mammoth molars from Jones Spring, MO, indicate a significant increase in MIS 3 seasonality, compared to the last interglacial period (MIS 5e). Finally, some mammoths in this study died $>200 \mathrm{~km}$ away from where they lived during the formation of sampled molars suggesting lifetime mobility patterns in mammoths could have a significant effect on presumed 
524 Styles, then at the Illinois State Museum; Rhiannon Stevens (University College of London) and

525 Matt G. Hill (Iowa State University). Additional conversations with Don Esker greatly clarified

526 micro-milling methods, and Joseph Andrew (University of Kansas) assisted with Sr isotope

527 analyses. Jeff Pigati and two anonymous reviewers provided invaluable feedback for

528 strengthening the manuscript. This research was funded by NSF grants 1050638, 1049885 and

5291050261 and the Illinois State Museum Society. Finally, we would like to acknowledge all of the 530 collections managers and curators who assisted us with access to the specimens within their care. 531 


\section{Figures}

Figure 1. Map of dated midwestern mammoths (blue) and mastodons (red) with associated $\delta^{13} \mathrm{C}_{\text {coll }}$ and $\delta^{15} \mathrm{~N}_{\text {coll }}$ data. See SM Table 2 for details.

Figure 2. Schematic illustration of serial and micro-sampling strategies.

Figure 3. Changes in midwestern proboscidean collagen $\delta^{13} \mathrm{C}$ and $\delta^{15} \mathrm{~N}$ through time.

Figure 4. Time series, serial enamel $\delta^{13} \mathrm{C}, \delta^{18} \mathrm{O},{ }^{87} \mathrm{Sr} /{ }^{86} \mathrm{Sr}$.

Figure 5. Time series, micro-sampled enamel $\delta^{13} \mathrm{C}, \delta^{18} \mathrm{O},{ }^{87} \mathrm{Sr} /{ }^{86} \mathrm{Sr}$. Both specimens are from Jones Spring, Hickory County, Missouri.

Figure 6. Mobility in mammoths from Jones Spring, Hickory Co., MO. Hatched areas indicate the range of ${ }^{87} \mathrm{Sr} /{ }^{86} \mathrm{Sr}$ values from mammoth molar ridge-plates. One mammoth (305JS77) exhibits local values. Two separate mammoths (232JS77, 64JS73) exhibit Sr values suggesting $>200 \mathrm{~km}$ movement from the central core of the Ozark uplift. This implies movement over multiple years that is at least six times larger than the maximum home range size documented in modern elephants (Netosha National Park, Namibia). Basemap isoscape data from Widga et al. (2017b), Hedman et al. (2009, 2018). Figure 7. Mastodon distribution during the Bølling-Allerød. Black circles indicate mastodon $\delta^{15} \mathrm{~N}_{\text {coll }}<5 \%$. Red circles represent mastodons with $\delta^{15} \mathrm{~N}_{\text {coll }}>5 \%$.

\section{Tables}

Table 1. Temporal Scale in Paleoecological Analyses.

Table 2. Mammoth and mastodon collagen stable isotope values, by chronzone.

Table 3. Summary of serial and micro-sampled tooth enamel series: $\delta^{13} \mathrm{C}, \delta^{18} \mathrm{O},{ }^{87} \mathrm{Sr} /{ }^{86} \mathrm{Sr}$. 


\section{Supplemental information}

SM Supplemental Material. Word File

SM Table 1. Mammoth and Mastodon $\delta^{13} \mathrm{C}, \delta^{15} \mathrm{~N}$ data.

SM Table 2. Mammoth enamel isotope data.

SM Table 3. Radiocarbon dated mammoths and mastodons from the Midwest.

\section{References}

Alley, Richard B. 2000. "The Younger Dryas Cold Interval as Viewed from Central Greenland." Quaternary Science Reviews 19 (1): 213-26. https://doi.org/10.1016/S02773791(99)00062-1.

Alroy, John. 2001. "A Multispecies Overkill Simulation of the End-Pleistocene Megafaunal Mass Extinction.” Science 292 (5523): 1893-96. https://doi.org/10.1126/science.1059342.

Arppe, Laura, Juha A. Karhu, Sergey Vartanyan, Dorothée G. Drucker, Heli Etu-Sihvola, and Hervé Bocherens. 2019. “Thriving or Surviving? The Isotopic Record of the Wrangel Island Woolly Mammoth Population.” Quaternary Science Reviews 222 (October): 105884. https://doi.org/10.1016/j.quascirev.2019.105884.

Augustine, David J., Samuel J. McNaughton, and Douglas A. Frank. 2003. "Feedbacks Between Soil Nutrients and Large Herbivores in a Managed Savanna Ecosystem." Ecological Applications 13 (5): 1325-37. https://doi.org/10.1890/02-5283.

Austin, Amy T., and P. M. Vitousek. 1998. "Nutrient Dynamics on a Precipitation Gradient in Hawai'i." Oecologia 113 (4): 519-29. https://doi.org/10.1007/s004420050405.

Bataille, Clément P., and Gabriel J. Bowen. 2012. "Mapping 87Sr/86Sr Variations in Bedrock and Water for Large Scale Provenance Studies.” Chemical Geology 304-305 (April): 3952. https://doi.org/10.1016/j.chemgeo.2012.01.028.

Baumann, Eric J., and Brooke E. Crowley. 2015. "Stable Isotopes Reveal Ecological Differences amongst Now-Extinct Proboscideans from the Cincinnati Region, USA." Boreas 44 (1): 240-54. https://doi.org/10.1111/bor.12091.

Birks, Hilary H., Bas van Geel, Daniel C. Fisher, Eric C. Grimm, Wim J. Kuijper, Jan van Arkel, and Guido B. A. van Reenen. 2019. "Evidence for the Diet and Habitat of Two Late Pleistocene Mastodons from the Midwest, USA." Quaternary Research 91 (2): 792-812. https://doi.org/10.1017/qua.2018.100.

Bocherens, Hervé, Gilles Pacaud, Petr A. Lazarev, and André Mariotti. 1996. "Stable Isotope Abundances $(13 \mathrm{C}, 15 \mathrm{~N})$ in Collagen and Soft Tissues from Pleistocene Mammals from Yakutia: Implications for the Palaeobiology of the Mammoth Steppe.” Palaeogeography, Palaeoclimatology, Palaeoecology, Biogenic Phosphates as Palaeoenvironmental Indicators, 126 (1): 31-44. https://doi.org/10.1016/S0031-0182(96)00068-5.

Brock, Fiona, Thomas Higham, Peter Ditchfield, and Christopher Bronk Ramsey. 2010. "Current Pretreatment Methods for AMS Radiocarbon Dating at the Oxford Radiocarbon 
Accelerator Unit (Orau)." Radiocarbon 52 (1): 103-12. https://doi.org/10.1017/S0033822200045069.

Broughton, Jack M., and Elic M. Weitzel. 2018. "Population Reconstructions for Humans and Megafauna Suggest Mixed Causes for North American Pleistocene Extinctions." Nature Communications 9 (1): 5441. https://doi.org/10.1038/s41467-018-07897-1.

Cerling, Thure E., George Wittemyer, James R. Ehleringer, Christopher H. Remien, and Iain Douglas-Hamilton. 2009. "History of Animals Using Isotope Records (HAIR): A 6-Year Dietary History of One Family of African Elephants." Proceedings of the National Academy of Sciences 106 (20): 8093-8100. https://doi.org/10.1073/pnas.0902192106.

Chafota, Jonas, and Norman Owen-Smith. 2009. "Episodic Severe Damage to Canopy Trees by Elephants: Interactions with Fire, Frost and Rain." Journal of Tropical Ecology 25 (3): 341-45. https://doi.org/10.1017/S0266467409006051.

Coe, Malcolm. 1978. "The Decomposition of Elephant Carcases in the Tsavo (East) National Park, Kenya." Journal of Arid Environments 1 (1): 71-86. https://doi.org/10.1016/S01401963(18)31756-7.

Coltrain, Joan Brenner, John M. Harris, Thure E. Cerling, James R. Ehleringer, Maria-Denise Dearing, Joy Ward, and Julie Allen. 2004. "Rancho La Brea Stable Isotope Biogeochemistry and Its Implications for the Palaeoecology of Late Pleistocene, Coastal Southern California." Palaeogeography, Palaeoclimatology, Palaeoecology 205 (3): 199-219. https://doi.org/10.1016/j.palaeo.2003.12.008.

Daniel Bryant, J., and Philip N. Froelich. 1995. "A Model of Oxygen Isotope Fractionation in Body Water of Large Mammals." Geochimica et Cosmochimica Acta 59 (21): 45234537. https://doi.org/10.1016/0016-7037(95)00250-4.

Daux, Valérie, Christophe Lécuyer, Marie Anne Héran, Romain Amiot, Laurent Simon, François Fourel, François Martineau, Niels Lynnerup, Hervé Reychler, and Gilles Escarguel. 2008. "Oxygen Isotope Fractionation between Human Phosphate and Water Revisited." Journal of Human Evolution 55 (6): 1138-1147. https://doi.org/10.1016/j.jhevol.2008.06.006.

Davis, Matt, and Silvia Pineda-Munoz. 2016. "The Temporal Scale of Diet and Dietary Proxies." Ecology and Evolution 6 (6): 1883-97. https://doi.org/10.1002/ece3.2054.

Delcourt, Hazel R., and P. Delcourt. 1991. Quaternary Ecology: A Paleoecological Perspective. Springer Science \& Business Media.

Denny, Mark W., Brian Helmuth, George H. Leonard, Christopher D. G. Harley, Luke J. H. Hunt, and Elizabeth K. Nelson. 2004. "Quantifying scale in ecology: lessons from a wave-swept shore.” Ecological Monographs 74 (3): 513-32. https://doi.org/10.1890/034043.

Dirks, Wendy, Timothy G. Bromage, and Larry D. Agenbroad. 2012. "The Duration and Rate of Molar Plate Formation in Palaeoloxodon Cypriotes and Mammuthus Columbi from Dental Histology." Quaternary International, Mammoths and Their Relatives 1: Biotopes, Evolution and Human Impact V International Conference, Le Puy-en-Velay, 2010, 255 (March): 79-85. https://doi.org/10.1016/j.quaint.2011.11.002.

Drucker, D. G., Bridault, A., Iacumin, P., \& Bocherens, H. (2009). Bone stable isotopic signatures $(15 \mathrm{~N}, 18 \mathrm{O})$ as tracers of temperature variation during the Late-glacial and early Holocene: case study on red deer Cervus elaphus from Rochedane (Jura, France). Geological Journal, 44(5), 593-604.

Drucker, Dorothée G., Rhiannon E. Stevens, Mietje Germonpré, Mikhail V. Sablin, Stéphane Péan, and Hervé Bocherens. 2018. "Collagen Stable Isotopes Provide Insights into the 
End of the Mammoth Steppe in the Central East European Plains during the Epigravettian." Quaternary Research 90 (3): 457-69. https://doi.org/10.1017/qua.2018.40.

El Adli, Joseph J., Michael D. Cherney, Daniel C. Fisher, John M. Harris, Farrell, Aisling, and Cox, Shelley. 2015. "Last Years of Life and Season of Death of a Columbian Mammoth from Rancho La Brea." Science Series, Natural History Museum of Los Angeles County 42: 65-80.

El Adli, Joseph J., Daniel C. Fisher, Sergey L. Vartanyan, and Alexei N. Tikhonov. 2017. "Final Years of Life and Seasons of Death of Woolly Mammoths from Wrangel Island and Mainland Chukotka, Russian Federation." Quaternary International, VIth International Conference on Mammoths and their Relatives, Part 3, 445 (July): 135-45. https://doi.org/10.1016/j.quaint.2016.07.017.

Esker, D., Forman, S. L., Widga, C., Walker, J. D., \& Andrew, J. E. (2019). Home range of the Columbian mammoths (Mammuthus columbi) and grazing herbivores from the Waco Mammoth National Monument,(Texas, USA) based on strontium isotope ratios from tooth enamel bioapatite. Palaeogeography, Palaeoclimatology, Palaeoecology, 534, 109291.

Fiedel, Stuart, Robert Feranec, Thomas Marino, and David Driver. 2019. "A New AMS Radiocarbon Date for the Ivory Pond Mastodon." Eastern Paleontologist 3: 1-15.

Fisher, Daniel C. 2009. "Paleobiology and Extinction of Proboscideans in the Great Lakes Region of North America." In American Megafaunal Extinctions at the End of the Pleistocene, edited by Gary Haynes, 55-75. Vertebrate Paleobiology and Paleoanthropology. Dordrecht: Springer Netherlands. https://doi.org/10.1007/978-14020-8793-6_4.

- 2018. "Paleobiology of Pleistocene Proboscideans." Annual Review of Earth and Planetary Sciences 46 (1): 229-60. https://doi.org/10.1146/annurev-earth-060115012437.

Fisher, Daniel C., and David L. Fox. 2006. "Five Years in the Life of an Aucilla River Mastodon." In First Floridians and Last Mastodons: The Page-Ladson Site in the Aucilla River, edited by S. David Webb, 343-77. Dordrecht: Springer Netherlands. https://doi.org/10.1007/978-1-4020-4694-0_12.

Fisher, Daniel C., Alexei N. Tikhonov, Pavel A. Kosintsev, Adam N. Rountrey, Bernard Buigues, and Johannes van der Plicht. 2012. "Anatomy, Death, and Preservation of a Woolly Mammoth (Mammuthus Primigenius) Calf, Yamal Peninsula, Northwest Siberia." Quaternary International, Mammoths and Their Relatives 1: Biotopes, Evolution and Human Impact V International Conference, Le Puy-en-Velay, 2010, 255 (March): 94-105. https://doi.org/10.1016/j.quaint.2011.05.040.

Fortelius, Mikael, and Nikos Solounias. 2000. "Functional Characterization of Ungulate Molars Using the Abrasion-Attrition Wear Gradient: A New Method for Reconstructing Paleodiets." American Museum Novitates 225 (4): 1-36. https://doi.org/10.1206/00030082(2000)301<0001:FCOUMU>2.0.CO;2.

Fox, David L., and Daniel C. Fisher. 2001. "Stable Isotope Ecology of a Late Miocene Population of Gomphotherium Productus (Mammalia, Proboscidea) from Port of Entry Pit, Oklahoma, USA.” PALAIOS 16 (3): 279-93. https://doi.org/10.1669/08831351(2001)016<0279:SIEOAL>2.0.CO;2.

Fox-Dobbs, K., J.K. Bump, R.O. Peterson, D.L. Fox, and P.L. Koch. 2007. "Carnivore-Specific 
Stable Isotope Variables and Variation in the Foraging Ecology of Modern and Ancient Wolf Populations: Case Studies from Isle Royale, Minnesota, and La Brea." Canadian Journal of Zoology 85 (4): 458-71. https://doi.org/10.1139/Z07-018.

Fox-Dobbs, Kena, Jennifer A. Leonard, and Paul L. Koch. 2008. "Pleistocene Megafauna from Eastern Beringia: Paleoecological and Paleoenvironmental Interpretations of Stable Carbon and Nitrogen Isotope and Radiocarbon Records." Palaeogeography, Palaeoclimatology, Palaeoecology 261 (1): 30-46. https://doi.org/10.1016/j.palaeo.2007.12.011.

Frank, Douglas A., R. David Evans, and Benjamin F. Tracy. 2004. "The Role of Ammonia Volatilization in Controlling the Natural ${ }^{15}$ N Abundance of a Grazed Grassland." Biogeochemistry 68 (2): 169-78. https://doi.org/10.1023/B:BIOG.0000025736.19381.91.

Fujiyoshi, Lei, Atsuko Sugimoto, Akemi Tsukuura, Asami Kitayama, M. Larry Lopez Caceres, Byambasuren Mijidsuren, Ariunaa Saraadanbazar, and Maki Tsujimura. 2017. "Spatial Variations in Larch Needle and Soil $\delta{ }^{15} \mathrm{~N}$ at a Forest-Grassland Boundary in Northern Mongolia." Isotopes in Environmental and Health Studies 53 (1): 54-69. https://doi.org/10.1080/10256016.2016.1206093.

Geel, Bas van, Daniel C. Fisher, Adam N. Rountrey, Jan van Arkel, Joost F. Duivenvoorden, Aline M. Nieman, Guido B. A. van Reenen, Alexei N. Tikhonov, Bernard Buigues, and Barbara Gravendeel. 2011. "Palaeo-Environmental and Dietary Analysis of Intestinal Contents of a Mammoth Calf (Yamal Peninsula, Northwest Siberia)." Quaternary Science Reviews 30 (27): 3935-46. https://doi.org/10.1016/j.quascirev.2011.10.009.

Gill, Jacquelyn L., John W. Williams, Stephen T. Jackson, Katherine B. Lininger, and Guy S. Robinson. 2009. "Pleistocene Megafaunal Collapse, Novel Plant Communities, and Enhanced Fire Regimes in North America.” Science 326 (5956): 1100-1103. https://doi.org/10.1126/science.1179504.

Gonzales, Leila M., and Eric C. Grimm. 2009. "Synchronization of Late-Glacial Vegetation Changes at Crystal Lake, Illinois, USA with the North Atlantic Event Stratigraphy." Quaternary Research 72 (2): 234-45. https://doi.org/10.1016/j.yqres.2009.05.001.

Gonzales, L.M., J.W. Williams, and E.C. Grimm. 2009. "Expanded Response-Surfaces: A New Method to Reconstruct Paleoclimates from Fossil Pollen Assemblages That Lack Modern Analogues." Quaternary Science Reviews 28 (27-28): 3315-32. https://doi.org/10.1016/j.quascirev.2009.09.005.

Green, Jeremy L., Larisa R. G. DeSantis, and Gregory James Smith. 2017. "Regional Variation in the Browsing Diet of Pleistocene Mammut Americanum (Mammalia, Proboscidea) as Recorded by Dental Microwear Textures." Palaeogeography, Palaeoclimatology, Palaeoecology 487 (December): 59-70. https://doi.org/10.1016/j.palaeo.2017.08.019. Guldemond, Robert, and Rudi Van Aarde. 2008. "A Meta-Analysis of the Impact of African Elephants on Savanna Vegetation.” The Journal of Wildlife Management 72 (4): 892-99. Handley, L. L., and J. A. Raven. 1992. "The Use of Natural Abundance of Nitrogen Isotopes in Plant Physiology and Ecology." Plant, Cell and Environment 15 (9): 965-85. https://doi.org/10.1111/j.1365-3040.1992.tb01650.x.

Hedges, Robert E. M., John G. Clement, C. David L. Thomas, and Tamsin C. O’Connell. 2007. "Collagen Turnover in the Adult Femoral Mid-Shaft: Modeled from Anthropogenic Radiocarbon Tracer Measurements." American Journal of Physical Anthropology 133 (2): 808-16. https://doi.org/10.1002/ajpa.20598.

Hedman, Kristin M., B. Brandon Curry, Thomas M. Johnson, Paul D. Fullagar, and Thomas E. 
Emerson. 2009. "Variation in Strontium Isotope Ratios of Archaeological Fauna in the Midwestern United States: A Preliminary Study.” Journal of Archaeological Science 36 (1): 64-73. https://doi.org/10.1016/j.jas.2008.07.009.

Hedman, Kristin M., Philip A. Slater, Matthew A. Fort, Thomas E. Emerson, and John M. Lambert. 2018. "Expanding the Strontium Isoscape for the American Midcontinent: Identifying Potential Places of Origin for Cahokian and Pre-Columbian Migrants." Journal of Archaeological Science: Reports 22 (September): 202-213. https://doi.org/10.1016/j.jasrep.2018.09.027.

Higham, T F G, R M Jacobi, and C B Ramsey. 2006. "AMS Radiocarbon Dating of Ancient Bone Using Ultrafiltration.” Radiocarbon 48 (2): 179-195. https://doi.org/10.2458/azu_js_rc.v48i2.2861.

Hobbie, E. A., S. A. Macko, and M. Williams. 2000. "Correlations between Foliar $\Delta 15 \mathrm{~N}$ and Nitrogen Concentrations May Indicate Plant-Mycorrhizal Interactions.” Oecologia 122 (2): 273-83. https://doi.org/10.1007/PL00008856.

Hoppe, Kathryn A. 2004. "Late Pleistocene Mammoth Herd Structure, Migration Patterns, and Clovis Hunting Strategies Inferred from Isotopic Analyses of Multiple Death Assemblages." Paleobiology 30 (1): 129-45. https://doi.org/10.1666/00948373(2004)030<0129:LPMHSM>2.0.CO;2.

Hoppe, Kathryn A., and Paul L. Koch. 2007. "Reconstructing the Migration Patterns of Late Pleistocene Mammals from Northern Florida, USA.” Quaternary Research 68 (3): 347 52. https://doi.org/10.1016/j.yqres.2007.08.001.

Hoppe, Kathryn A., Paul L. Koch, Richard W. Carlson, and S. David Webb. 1999. "Tracking Mammoths and Mastodons: Reconstruction of Migratory Behavior Using Strontium Isotope Ratios." Geology 27 (5): 439-42. https://doi.org/10.1130/00917613(1999)027<0439:TMAMRO>2.3.CO;2.

Iacumin, P., A. Di Matteo, V. Nikolaev, and T. V. Kuznetsova. 2010. "Climate Information from C, N and O Stable Isotope Analyses of Mammoth Bones from Northern Siberia." Quaternary International, Quaternary Changes of Mammalian Communities Across and Between Continents, 212 (2): 206-12. https://doi.org/10.1016/j.quaint.2009.10.009.

Keenan, Sarah W., Chris Widga, Debruyn, Jennifer, and schaeffer, sean. 2018. "Nutrient Hotspots through Time: A Field Guide to Modern and Fossil Taphonomy in East Tennessee." In Geology at Every Scale, by Annette Summers Engel and Robert D. Hatcher, 61-74. Geological Society of America. https://doi.org/10.1130/2018.0050(04).

King, J. E. (1973). Late Pleistocene palynology and biogeography of the western Missouri Ozarks. Ecological Monographs, 43(4): 539-565.

Knapp, Alan K, John M Blair, John M Briggs, Scott L Collins, David C Hartnett, Loretta C Johnson, E Gene Towne, M John, and L Scott. 1999. "North Keystone Role of Bison in American Tallgrass Prairie Bison Increase Habitat Heterogeneity and Alter a Broad Array of Processes" 49 (1): 39-50.

Koch, Paul L., Kathryn A. Hoppe, and S. David Webb. 1998. "The Isotopic Ecology of Late Pleistocene Mammals in North America: Part 1. Florida." Chemical Geology 152 (1): 119-38. https://doi.org/10.1016/S0009-2541(98)00101-6.

Koch, Paul L., Noreen Tuross, and Marilyn L. Fogel. 1997. "The Effects of Sample Treatment and Diagenesis on the Isotopic Integrity of Carbonate in Biogenic Hydroxylapatite." Journal of Archaeological Science 24 (5): 417-429. https://doi.org/10.1006/jasc.1996.0126. 
Lee-Thorp, Julia, and Matt Sponheimer. 2003. "Three Case Studies Used to Reassess the Reliability of Fossil Bone and Enamel Isotope Signals for Paleodietary Studies." Journal of Anthropological Archaeology 22 (3): 208-216. https://doi.org/10.1016/S02784165(03)00035-7.

Lepper, Bradley T., Tod A. Frolking, Daniel C. Fisher, Gerald Goldstein, Jon E. Sanger, Dee Anne Wymer, J. Gordon Ogden, and Paul E. Hooge. 1991. "Intestinal Contents of a Late Pleistocene Mastodont from Midcontinental North America." Quaternary Research 36 (1): 120-25. https://doi.org/10.1016/0033-5894(91)90020-6.

McNaughton, S. J., R. W. Ruess, and S. W. Seagle. 1988. "Large Mammals and Process Dynamics in African Ecosystems." BioScience 38 (11): 794-800. https://doi.org/10.2307/1310789.

Metcalfe, Jessica Z., and Fred J. Longstaffe. 2012. "Mammoth Tooth Enamel Growth Rates Inferred from Stable Isotope Analysis and Histology." Quaternary Research 77 (3): 424 32. https://doi.org/10.1016/j.yqres.2012.02.002.

. 2014. "Environmental Change and Seasonal Behavior of Mastodons in the Great Lakes Region Inferred from Stable Isotope Analysis." Quaternary Research 82 (2): 366-77. https://doi.org/10.1016/j.yqres.2014.07.002.

Metcalfe, Jessica Z., Fred J. Longstaffe, Jesse A. M. Ballenger, and C. Vance Haynes. 2011. "Isotopic Paleoecology of Clovis Mammoths from Arizona." Proceedings of the National Academy of Sciences 108 (44): 17916-20. https://doi.org/10.1073/pnas.1113881108.

Metcalfe, Jessica Z., Fred J. Longstaffe, and Greg Hodgins. 2013. "Proboscideans and Paleoenvironments of the Pleistocene Great Lakes: Landscape, Vegetation, and Stable Isotopes." Quaternary Science Reviews 76 (September): 102-13. https://doi.org/10.1016/j.quascirev.2013.07.004.

Michelsen, Anders, Chris Quarmby, Darren Sleep, and Sven Jonasson. 1998. "Vascular Plant 15 N Natural Abundance in Heath and Forest Tundra Ecosystems Is Closely Correlated with Presence and Type of Mycorrhizal Fungi in Roots." Oecologia 115 (3): 406-18. https://doi.org/10.1007/s004420050535.

Mosimann, James E., and Paul S. Martin. 1975. "Simulating Overkill by Paleoindians: Did Man Hunt the Giant Mammals of the New World to Extinction? Mathematical Models Show That the Hypothesis Is Feasible.” American Scientist 63 (3): 304-13.

Newsom, Lee A., and Mathew C. Mihlbachler. 2006. "Mastodons (Mammut Americanum) Diet Foraging Patterns Based on Analysis of Dung Deposits." In First Floridians and Last Mastodons: The Page-Ladson Site in the Aucilla River, edited by S. David Webb, 263331. Springer Netherlands. https://doi.org/10.1007/978-1-4020-4694-0_10.

Ngene, Shadrack, Moses Makonjio Okello, Joseph Mukeka, Shadrack Muya, Steve Njumbi, and James Isiche. 2017. Home range sizes and space use of African elephants (Loxodonta africana) in the Southern Kenya and Northern Tanzania borderland landscape. International Journal of Biodiversity and Conservation 9(1): 9-26.

Nogués-Bravo, David, Jesús Rodríguez, Joaquín Hortal, Persaram Batra, and Miguel B. Araújo. 2008. "Climate Change, Humans, and the Extinction of the Woolly Mammoth." PLOS Biology 6 (4): e79. https://doi.org/10.1371/journal.pbio.0060079.

Owen-Smith, R. Norman. 1992. Megaherbivores: The Influence of Very Large Body Size on Ecology. Cambridge University Press.

Pacher, Martina, and Anthony J. Stuart. 2009. "Extinction Chronology and Palaeobiology of the Cave Bear (Ursus Spelaeus).” Boreas 38 (2): 189-206. https://doi.org/10.1111/j.1502- 
3885.2008.00071.x.

Pérez-Crespo, Víctor Adrián, Peter Schaaf, Gabriela Solís-Pichardo, Joaquín Arroyo-Cabrales, Luis M. Alva-Valdivia, and José Ramón Torres-Hernández. 2016. "Strontium Isotopes and Mobility of a Columbian Mammoth (Mammuthus Columbi) Population, Laguna de Las Cruces, San Luis Potosí, México.” Geological Magazine 153 (4): 743-49. https://doi.org/10.1017/S001675681500103X.

Plumptre, A. J. 1994. "The Effects of Trampling Damage by Herbivores on the Vegetation of the Pare National Des Volcans, Rwanda." African Journal of Ecology 32 (2): 115-29. https://doi.org/10.1111/j.1365-2028.1994.tb00563.x.

Post, David M. 2002. "Using Stable Isotopes to Estimate Trophic Position: Models, Methods, and Assumptions." Ecology 83 (3): 703-718. https://doi.org/10.1890/00129658(2002)083[0703:USITET]2.0.CO;2.

Rabanus-Wallace, M. Timothy, Matthew Wooller, Grant Zazula, Elen Shute, A Hope Jahren, Pavel Kosintsev, James Burns, James Breen, Bastien Llamas, and Alan Cooper. 2017. Megafaunal isotopes reveal role of increase moisture on rangeland during late Pleistocene extinctions. Nature Ecology and Evolution 1(0125). https://doi.org/10:1038/s41559-0170125.

Rasmussen, Sune O., Matthias Bigler, Simon P. Blockley, Thomas Blunier, Susanne L. Buchardt, Henrik B. Clausen, Ivana Cvijanovic et al. 2014. A stratigraphic framework for abrupt climatic changes during the Last Glacial period based on three synchronized Greenland ice-core records: refining and extending the INTIMATE event stratigraphy. Quaternary Science Reviews 106: 14-28.

Rhodes, A. N., J. W. Urbance, H. Youga, H. Corlew-Newman, C. A. Reddy, M. J. Klug, J. M. Tiedje, and D. C. Fisher. 1998. "Identification of Bacterial Isolates Obtained from Intestinal Contents Associated with 12,000-Year-Old Mastodon Remains." Appl. Environ. Microbiol. 64 (2): 651-58.

Richards, M. P. and R. E. M. Hedges. 2003. Variations in bone collagen $\delta^{13} \mathrm{C}$ and $\delta^{15} \mathrm{~N}$ values of fauna from Northwest Europe over the last 40,000 years. Palaeogeography, Palaeoclimatology, and Palaeoecology 193:261-267.

Ripple, William J., and Blaire Van Valkenburgh. 2010. "Linking Top-down Forces to the Pleistocene Megafaunal Extinctions.” BioScience 60 (7): 516-26. https://doi.org/10.1525/bio.2010.60.7.7.

Rountrey, Adam N., Daniel C. Fisher, Alexei N. Tikhonov, Pavel A. Kosintsev, Pyotr A. Lazarev, Gennady Boeskorov, and Bernard Buigues. 2012. "Early Tooth Development, Gestation, and Season of Birth in Mammoths." Quaternary International, Mammoths and Their Relatives 1: Biotopes, Evolution and Human Impact V International Conference, Le Puy-en-Velay, 2010, 255 (March): 196-205. https://doi.org/10.1016/j.quaint.2011.06.006.

Sah, S. P., H. Rita, and H. Ilvesniemi. 2006. "15N Natural Abundance of Foliage and Soil across Boreal Forests of Finland." Biogeochemistry 80 (3): 277-288. https://doi.org/10.1007/s10533-006-9023-9.

Saunders, Jeffrey J., Eric C. Grimm, Christopher C. Widga, G. Dennis Campbell, B. Brandon Curry, David A. Grimley, Paul R. Hanson, Judd P. McCullum, James S. Oliver, and Janis D. Treworgy. 2010. "Paradigms and Proboscideans in the Southern Great Lakes Region, USA." Quaternary International 217 (1-2): 175-87. https://doi.org/10.1016/j.quaint.2009.07.031. 
Schubert, B. A., \& Jahren, A. H. (2015). Global increase in plant carbon isotope fractionation following the Last Glacial Maximum caused by increase in atmospheric p CO2. Geology, 43(5): 435-438.

Schulze, E.-D., F. S. Chapin, and G. Gebauer. 1994. "Nitrogen Nutrition and Isotope Differences among Life Forms at the Northern Treeline of Alaska." Oecologia 100 (4): 406-12. https://doi.org/10.1007/BF00317862.

Schwartz-Narbonne, R., F. J. Longstaffe, K. J. Kardynal, P. Druckenmiller, K. A. Hobson, C. N. Jass, J. Z. Metcalfe, G. Zazula. 2019. "Reframing the mammoth steppe: Insights from analysis of isotopic niches. Quaternary Science Reviews 215: 1-21.

Shearer, G, and D Kohl. 1993. "Natural Abundance of 15N: Fractional Contribution of Two Sources to a Common Sink and Use of Isotope Discrimination." In Nitrogen Isotope Techniques, 89-125. Academic Press.

Slater, Philip A., Kristin M. Hedman, and Thomas E. Emerson. 2014. "Immigrants at the Mississippian Polity of Cahokia: Strontium Isotope Evidence for Population Movement." Journal of Archaeological Science 44 (April): 117-27. https://doi.org/10.1016/j.jas.2014.01.022.

Smith, Gregory James, and Larisa R. G. DeSantis. 2018. "Dietary Ecology of Pleistocene Mammoths and Mastodons as Inferred from Dental Microwear Textures." Palaeogeography, Palaeoclimatology, Palaeoecology 492 (March): 10-25. https://doi.org/10.1016/j.palaeo.2017.11.024.

Stevens, Rhiannon, Roger Jacobi, Martin Street, Mietje Germonpre, Nicholas Conard, Susanne Munzel, Robert E. M. Hedges. 2008. Nitrogen isotope analyses of reindeer (Rangifer tarandus), 45,000 BP to 9,000 BP: Palaeoenvironmental reconstructions. Palaeogeography, Palaeoclimatology, Palaeoecology 262: 32-45.

Stuart, A. J., P. A. Kosintsev, T. F. G. Higham, and A. M. Lister. 2004. "Pleistocene to Holocene Extinction Dynamics in Giant Deer and Woolly Mammoth.” Nature 431 (7009): 684. https://doi.org/10.1038/nature02890.

Stuart, Anthony J., and Adrian M. Lister. 2011. "Extinction Chronology of the Cave Lion Panthera Spelaea." Quaternary Science Reviews, Beringia and Beyond: Papers Celebrating the Scientific Career of Andrei Vladimirovich Sher, 1939-2008, 30 (17): 2329-40. https://doi.org/10.1016/j.quascirev.2010.04.023.

. 2012. "Extinction Chronology of the Woolly Rhinoceros Coelodonta Antiquitatis in the Context of Late Quaternary Megafaunal Extinctions in Northern Eurasia." Quaternary Science Reviews 51 (September): 1-17. https://doi.org/10.1016/j.quascirev.2012.06.007.

Stuart, Anthony John. 2015. "Late Quaternary Megafaunal Extinctions on the Continents: A Short Review." Geological Journal 50 (3): 338-63. https://doi.org/10.1002/gj.2633.

Surovell, Todd A., Spencer R. Pelton, Richard Anderson-Sprecher, and Adam D. Myers. 2016. "Test of Martin's Overkill Hypothesis Using Radiocarbon Dates on Extinct Megafauna." Proceedings of the National Academy of Sciences 113 (4): 886-91. https://doi.org/10.1073/pnas.1504020112.

Surovell, Todd, Nicole Waguespack, and P. Jeffrey Brantingham. 2005. "Global Archaeological Evidence for Proboscidean Overkill." Proceedings of the National Academy of Sciences 102 (17): 6231-36. https://doi.org/10.1073/pnas.0501947102.

Szpak, Paul, Darren R. Gröcke, Regis Debruyne, Ross D. E. MacPhee, R. Dale Guthrie, Duane Froese, Grant D. Zazula, William P. Patterson, and Hendrik N. Poinar. 2010. "Regional Differences in Bone Collagen $\delta^{13} \mathrm{C}$ and $\delta^{15} \mathrm{~N}$ of Pleistocene Mammoths: Implications for 
Paleoecology of the Mammoth Steppe." Palaeogeography, Palaeoclimatology, Palaeoecology 286 (1): 88-96. https://doi.org/10.1016/j.palaeo.2009.12.009.

Teale, Chelsea L., and Norton G. Miller. 2012. "Mastodon Herbivory in Mid-Latitude LatePleistocene Boreal Forests of Eastern North America.” Quaternary Research 78 (1): 72 81. https://doi.org/10.1016/j.yqres.2012.04.002.

Tuross, Noreen, Marilyn L Fogel, and P. E Hare. 1988. "Variability in the Preservation of the Isotopic Composition of Collagen from Fossil Bone." Geochimica et Cosmochimica Acta 52 (4): 929-35. https://doi.org/10.1016/0016-7037(88)90364-X.

Uno, Kevin T., Jay Quade, Daniel C. Fisher, George Wittemyer, Iain Douglas-Hamilton, Samuel Andanje, Patrick Omondi, Moses Litoroh, and Thure E. Cerling. 2013. "Bomb-Curve Radiocarbon Measurement of Recent Biologic Tissues and Applications to Wildlife Forensics and Stable Isotope (Paleo)Ecology." Proceedings of the National Academy of Sciences 110 (29): 11736-41. https://doi.org/10.1073/pnas.1302226110.

Valeix, Marion, Hervé Fritz, Rodolphe Sabatier, Felix Murindagomo, David Cumming, and Patrick Duncan. 2011. "Elephant-Induced Structural Changes in the Vegetation and Habitat Selection by Large Herbivores in an African Savanna." Biological Conservation 144 (2): 902-12. https://doi.org/10.1016/j.biocon.2010.10.029.

Voelker, Steven L., Michael C. Stambaugh, Richard P. Guyette, Xiahong Feng, David a. Grimley, Steven W. Leavitt, Irina Panyushkina, et al. 2015. "Deglacial Hydroclimate of Midcontinental North America." Quaternary Research 83 (2): 336-344. https://doi.org/10.1016/j.yqres.2015.01.001.

Warinner, Christina, and Noreen Tuross. 2010. "Brief Communication: Tissue Isotopic Enrichment Associated with Growth Depression in a Pig: Implications for Archaeology and Ecology." American Journal of Physical Anthropology 141 (3): 486-493. https://doi.org/10.1002/ajpa.21222.

Widga, Chris, Stacey N. Lengyel, Jeffrey Saunders, Gregory Hodgins, J. Douglas Walker, and Alan D. Wanamaker. 2017a. "Late Pleistocene Proboscidean Population Dynamics in the North American Midcontinent." Boreas 46 (4): 772-82. https://doi.org/10.1111/bor.12235.

Widga, Chris, J. Douglas Walker, and Andrew Boehm. 2017b. "Variability in Bioavailable ${ }^{87} \mathrm{Sr} /{ }^{86} \mathrm{Sr}$ in the North American Midcontinent." Open Quaternary 3 (1): 4. https://doi.org/10.5334/oq.32.

Wolverton, Steve, R Lee Lyman, James H Kennedy, and Thomas W La Point. 2009. "The Terminal Pleistocene Extinctions in North America, Hypermorphic Evolution, and the Dynamic Equilibrium Model.” Journal of Ethobiology 29 (1): 28-63. https://doi.org/10.2993/0278-0771-29.1.28.

Zazzo, Antoine, Marie Balasse, and William P. W.P. William P Patterson. 2006. "The Reconstruction of Mammal Individual History: Refining High-Resolution Isotope Record in Bovine Tooth Dentine." Journal of Archaeological Science 33 (8): 1177-1187. https://doi.org/10.1016/j.jas.2005.12.006. 


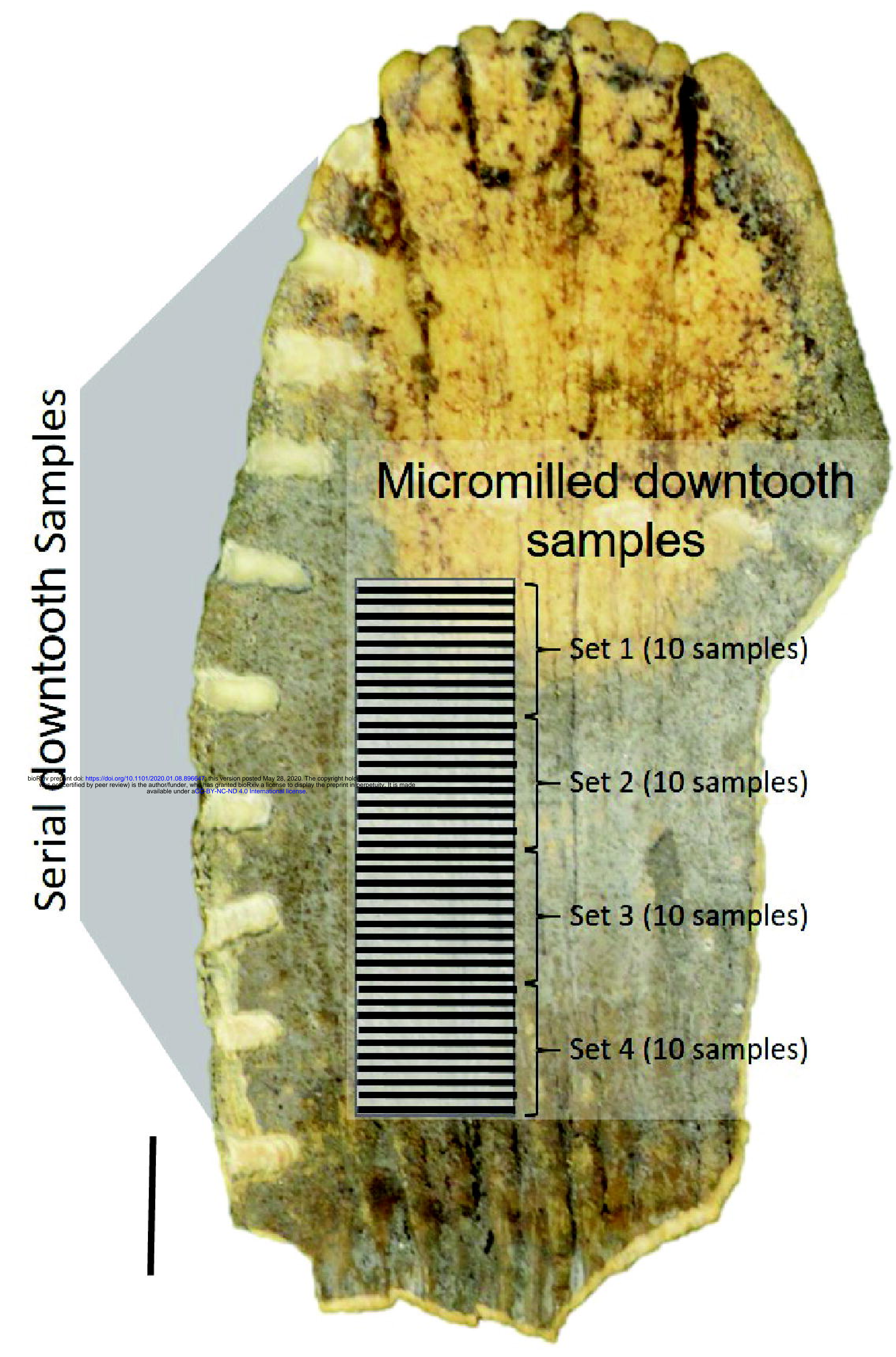

Cross Section of enamel sampling set showing milling depth.

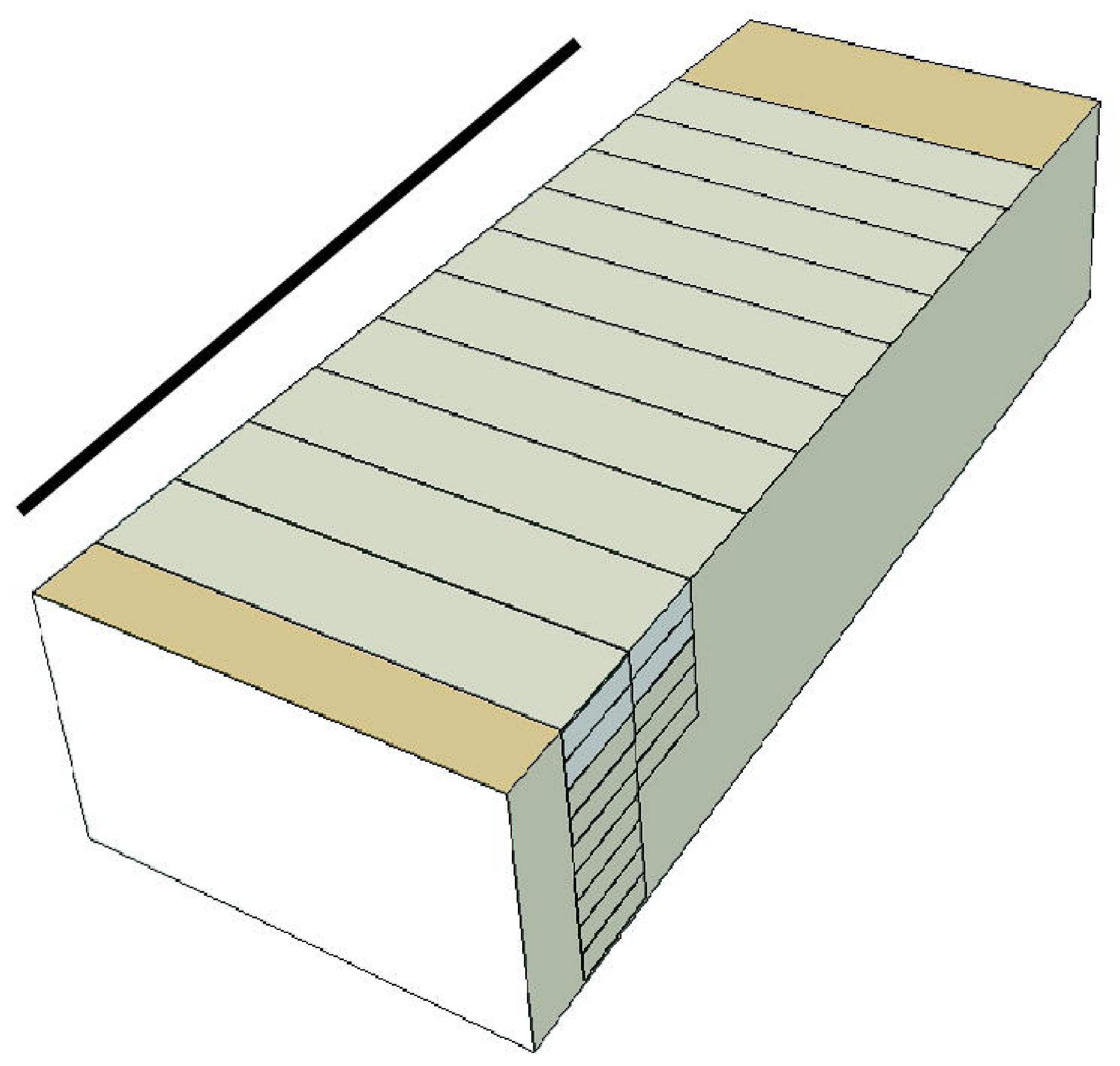

Enamel Sampling set.

Set 2 Sampla 10 od ation̈

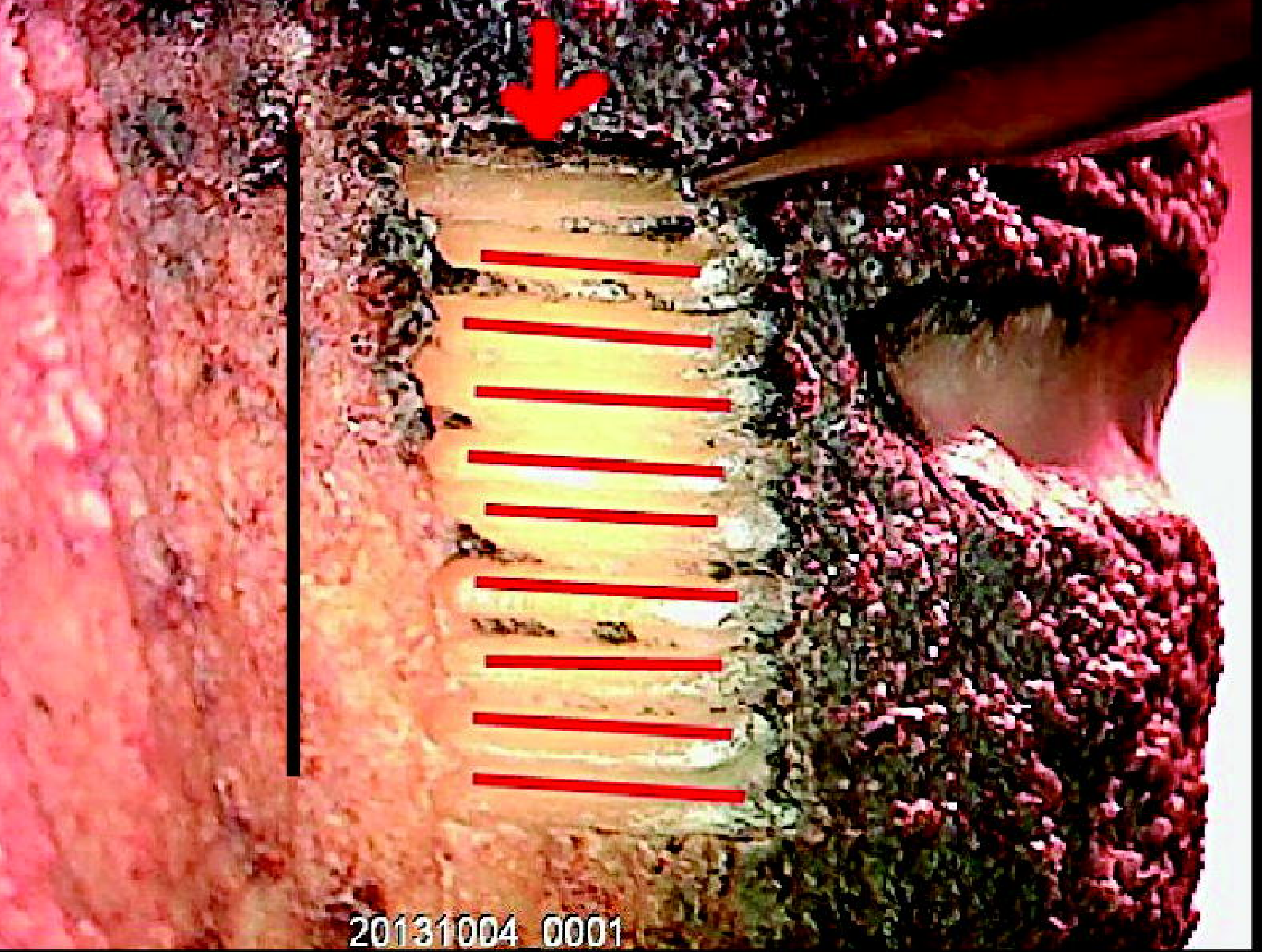




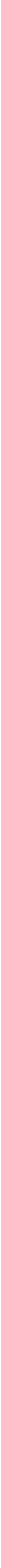




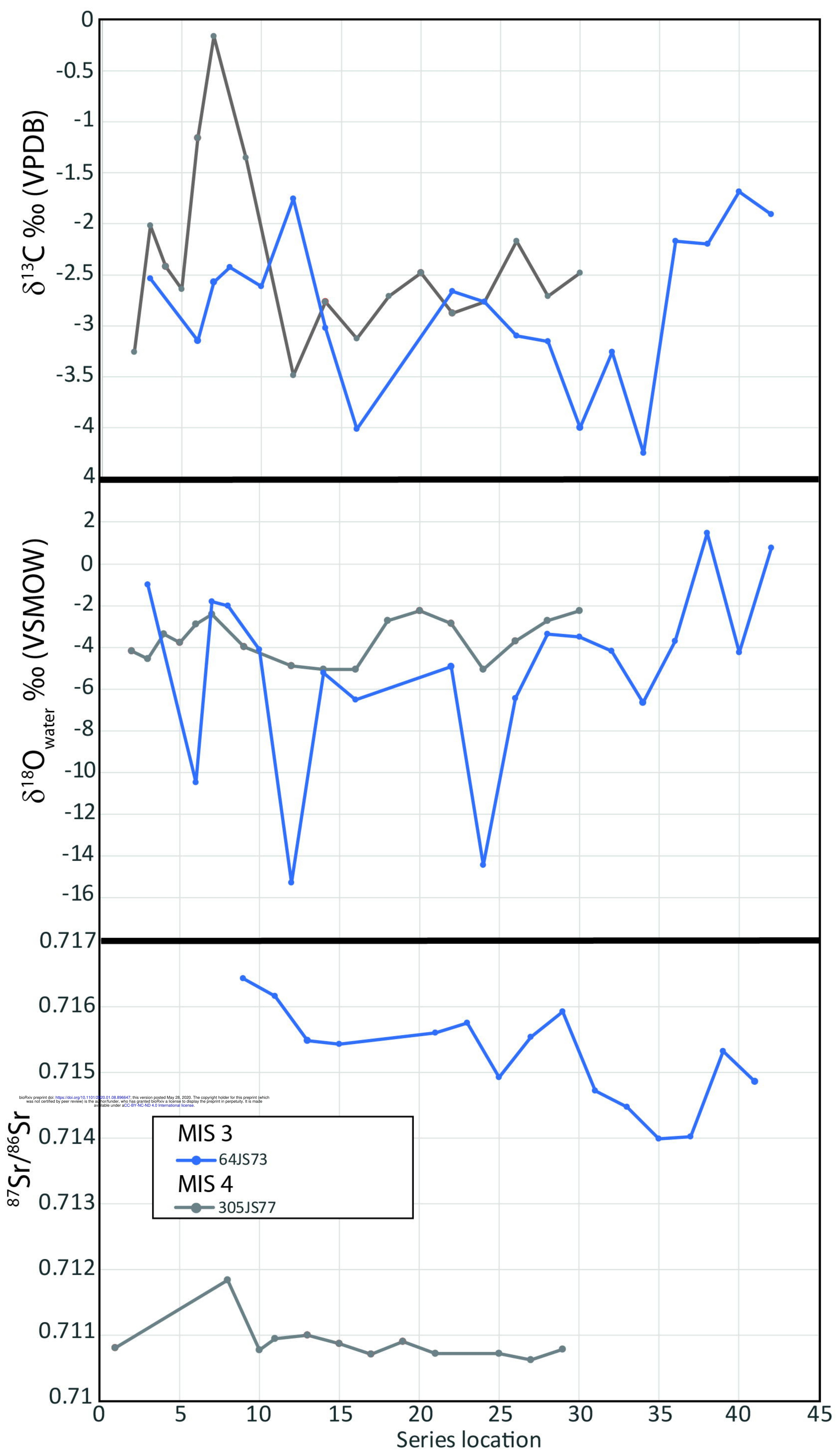




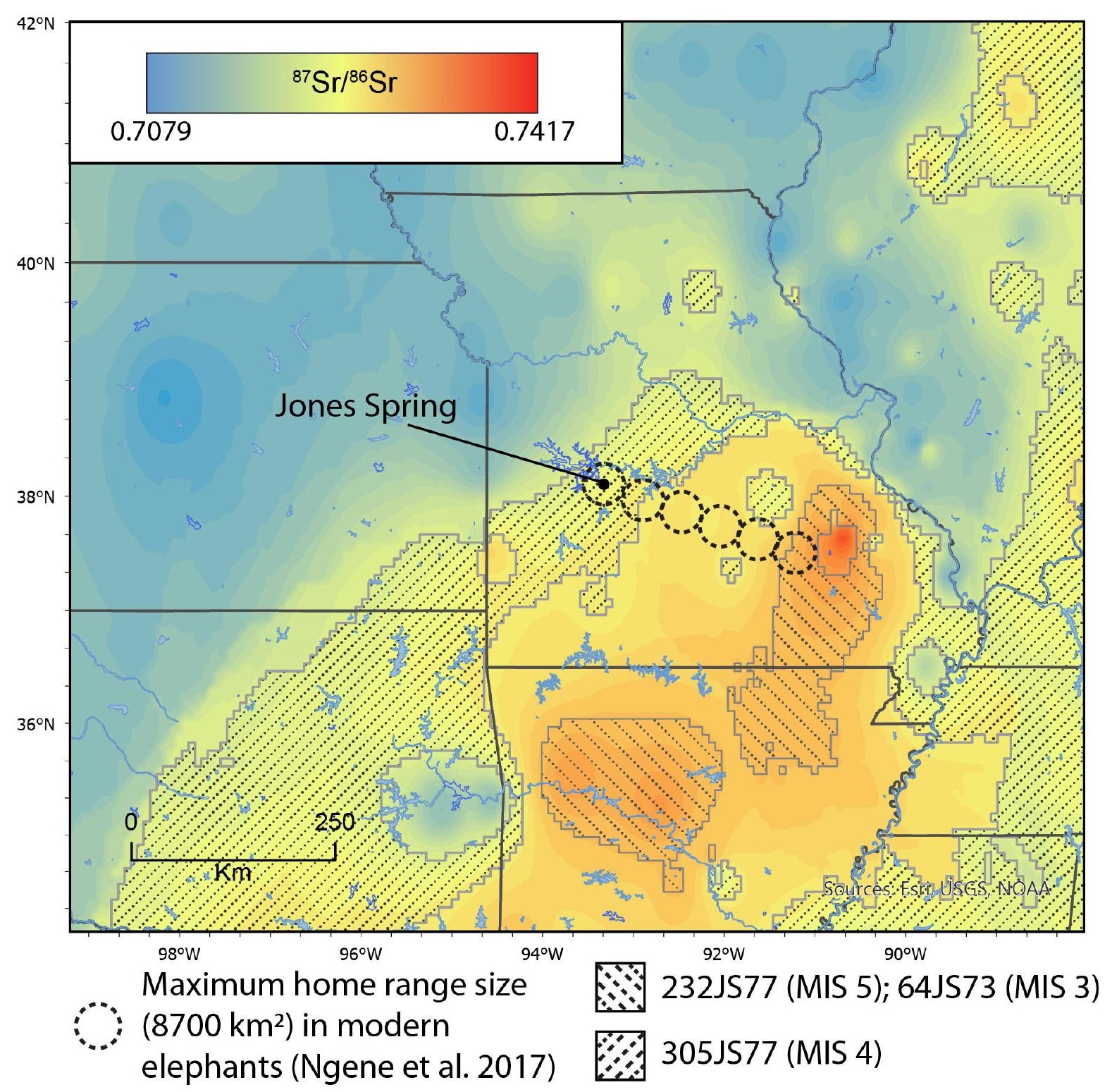




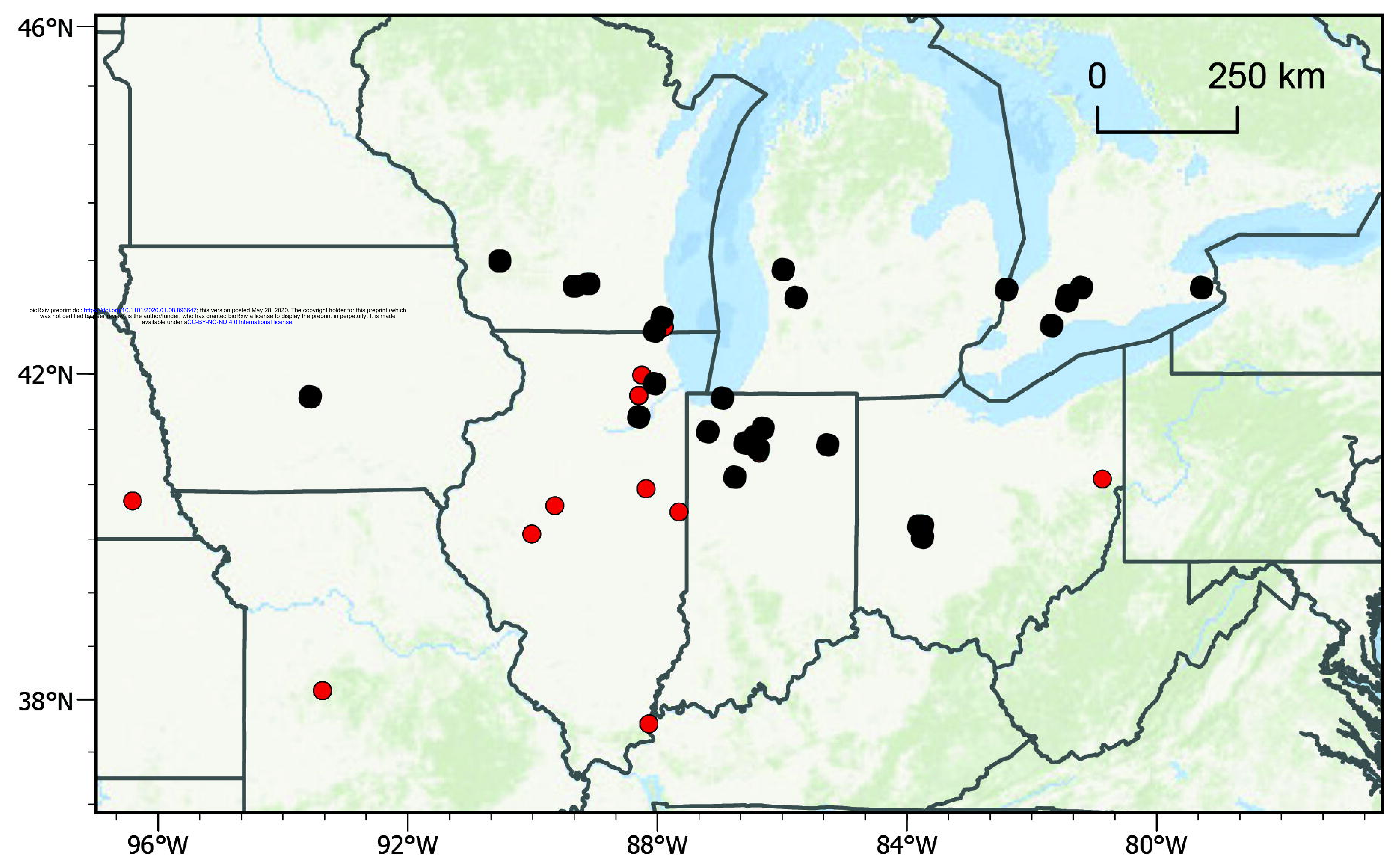

